\section{脳血管障 害}

\section{9. 脳卒中の疫学的研究（第 5 報）}

一高血圧管理と脳卒中発症に関する

検討を中心に一

薄井哲哉 伊藤良雄 森沢 康 松崎俊久 柴田茂男 西田 毅 平岩章好 林 直樹 沢井広量 小沢英舗 橋本 甫 柴田 博 小林太刀夫 (東大 第 4 内科)

高血圧の管理と脳血管性障害との関係については多く の研究者によって報告されているが, 必ずしもその見解 は一致していない。

今回, 山梨県白州町住民 40 才以上の高血圧症を対象 として昭和 40 年 8 月より高血圧の管理を行ない以下の 知見をえた。

〔対象ならびに方法〕昭和 40 年 7 月に測定した血圧值 妾 WHO の高血圧の基準に徒って判定し，以前測定し た 3 回の血圧值を参考にした．脳血管性障害を有するも のを除く高血圧 357 人を対象にした．新しく発症した例 では発作前にえられた血圧值によった．年令補正は非治 療群の年令構成を基準にして行なった，降俚薬は原則と してサイアザイドをべースとした.

〔成績】 (1高血圧 357 人のなかから 3 年間に新たに 37例の脳血管性障害の発症をみた．その内訳は非治療群 200 人中 25 例, 継続治療群 63 人中 4 例, 治療中断群 94 人中 8 例であった.

(2)脳出血の発病率は非治療群は 1,000 人対 45 を示し たが継続治療群は 16 と減少の傾向を認めた．治療中断 群は 21 であった。脳血栓の発病率は非治療群 1,000 人 対 75 , 継籶治療群 48 , 治療中断群 64 であった。脳出 血脳血栓比は非治療群の 0.6 に対し継続治療群は 0.33 と減少する傾向を示す成績がえられた。

(3)拡張期圧 $20 \%$ 以上の降圧がみられたか，あるいは $95 \mathrm{mmFig}$ 以下の正常血圧まで降圧した管理良好群から は現在までのところ脳血管性障害の発症はなく，管理不 良群に対して推計学的に有意である $\left(\chi^{2}=7.19, k<0.01\right)$.

(4)昭和 40 年 8 月前後の 3 年間の脳血管性障害の発病 率を比較すると前 3 年間の 99 に対して 104 と増加して いる. 昭和 37 年の年令を基準に年令補正を行な 5 と脳
出血は 17 人から 15.4 人に減少しているのに対し, 脳 血栓は 28 人から 30.7 人と増加する傾向を認めた.

\section{0. 脳卒中の研究（第 46 報）}

一久山町在住者 (40 才以上) の血圧值と 各種要因の検討一

広田安夫 勝木司馬之助 竹下司恭

中野昌弘 田中精二 池田寿雄 <勝木内科 $>$ 河野和正＜教養部>（九大）

浅野長一郎 藤元春海（塩野義解析センター）

福岡県久山町の 40 才以上の在住者を対象とした昭和 42 年の検診時血圧值およびアンケートを用い， 6 因子 2 水準直交配列に上る $2^{6}$ 型要因分析法によって年令（中 年と老年), 性別 (男と女), 降圧剂投与 (有無), 学働 (軽重), 男子のみで飲酒ならびに喫煙習慣 (有無), 女 子のみで脳卒中の家族歴（有無）ならびに生活水準（高 低）以上 8 個の因子の血圧值に及流す要因効果を主効 果と 2 因子交互作用に区分して検討した．WHO 基準の 非高血圧者すなわち正常血圧者と境界高血圧者（男 273 名, 女 410名) では, 性別, 収縮期ならびに拡張期血 圧を問わず降圧療法が有意であったが，これは血圧の高 い者が降圧療法を受けたためと考兄られた．次に男子で は飲酒習慣が収縮期ならびに拡張期血圧ともに有意で, 労働も收縮期 血圧で有意であり，いずれる血圧を高め るごとくであった．女子では収縮期血圧で脳卒中の家族 歴が，また㧪張期血圧では生活水準が有意であったが， 前者では家族歴があれば血圧を高め; 後者では高い生活 水準は比較的に低い血圧值と関連するごとくであった。 また，有意と認められた 2 因子交互作用は男子の収縮期 血圧に及ぼす年令と降圧療法, 労働と降圧療法ならびに 女子収縮期血圧に及涩す生活水準と脳卒中の家族歴であ ったが, いずれもその解釈は合理的に可能であった，高 血圧者 (男) 100 名, ‘ 99 名) について子同梯の要因 分析を試みたが，非高血圧者にみられたごとき有意の因 子を見出しえなかった：

この理由は, '高血圧者では残渣の標準偏差がより大で あったためと考兄られた。 


\section{1. 章森県下における治療中の} 脳卒中患者の調查成樍

木村新三 熊谷 宏 梅原 裕 (弘前大 畝研) 青森県下各医療機関への調查票の発送件数は 41 年度 が 786 件で, 回収された件数は 497 件で, その回収率 は $63.2 \%$ であった. えられた脳卒中患者数は 2733 名 であった. 42 年度では発送件数は 852 件で, 回収され た件数は 517 件で，その回収率は $60.6 \%$ 。゙あった。 え られた患者数は 2,483 名であった.

41 年度の患者数 2,733 名中, 男子 1,713 名, 女子 1,020 名で, 男子は女子の約 1.7 倍多く,この傾向は 42 年度にもみられた. また病型別に観察すると, 脸硬塞 患者の場合は, 41 年度打よび 42 年度で男子にやや多い 傾向 (41 年度男子 $31.5 \%$, 女子 $26.6 \%, 42$ 年男子 36.5 $\%$ ，女子 $32.9 \%)$ がみられ，脳出血の場合は 41 年度 で女子にやや多い傾向（男子 $52.8 \%$ ，女子 $58.3 \%$ ）が みられたが，42 年度では約 55\%で男女ともに大体同じ 傾向であった。

41 年度調查の男子硬塞発病平均年令は $61.5 \pm 0.3$ 才, 脳出血 $58.7 \pm 0.4$ 才であった. 女子の場合も脳便塞 64.1 \pm 0.6 才, 脳出血 $60.3 \pm 0.4$ 才であった。 脳硬塞と脳 出血の発病平均年令の 差は性別に関係なく有意（0.001 $>P)$ であり，また男子全体の発病平均年令は $59.5 \pm$ 0.2 才, 女子 $61.1 \pm 0.3$ 才で, その性差は有意 $(0.001>$

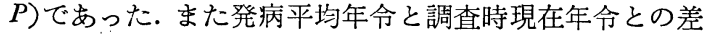
は 41 年度では男子脳硬塞 1.3 才, 男子脳出血 2.1 才, 女子脳硬塞 1.4 才, 女子脳出血 2.0 才であった. 敛硬 塞の場合より脳出血の場合の方がこの年令差が大きい傾 向がみられた. 42 年度調査でも，これとまったく同じ 傾向がみられた。

調查時現在の ADL は男子の場合は, 脳出血患者にそ の後遺症の重いものが多く, 軽症な患者は脳硬塞の場合 より少ない傾向がみられたが，女子については，この傾 向は認められなかった．また女子は女子全体の $29.1 \%$ が臥床中の患者で男子 $23.4 \%$ より多い傾向がみられた. ADL はその発病年令による差がみられ，後遺症の重い ものほど, 高年令のものが多く, 後遺症の軽いものほど, 若い患者が多い傾向が認められた。

問：小町喜男（大阪成人病七ンタ一）比較的年令 の若いときに発作を起こした脳卒中生存例に, 日常生活 可能のものの割合が多いことを示されたが，その年令層 のものの脳卒中死亡はどうなっているか.
6 巻 2 号 $(1969: 3)$

\section{2. 脳卒中の発生要因の検討と管理の効果}

島本 喬 飯田 稔 近山行夫 小町喜男 （大阪成人病センター 調査部）

われわれは成人循環器疾患（高血圧, 動脈硬化症) の 疫学調査に当っては, 地域, 職域別にこれを検討し, そ のおのおのの特性に基づく循環器疾患の成り立ちを検討 する必要のあることを報告した．脳卒中の分析に当って もこれと同じ観点から，地域，職域を異にした対象（地 域集団 9,200 人，職域集団 3,300 人）について最近 4 年間に新しく発作を起こした脸卒中のうち，検査所見も. そろい発作時年令が 40〜69 才のもの 124 例について分 析を行った.なお検討の対象とした検査内容は, 予診, 血圧, 肥満度, 眼底, 心電図 (全例) と血液化学所見で ある.成績は次のと㧊りである。

1）脳出血症例は農村, 都市を問わず高血圧性変化を 著明に受けている。

2）脳軟化はその発生要因について，従来より虚血性 心疾患のそれと同一のものを考えることを示唆する傾向 がみられたが，われわれの調査では次の 3 つに大別され. ることがわかった（11高血圧性変化を強く受けているも の(この数は後の 2 者に比し圧倒的に多い), (2)検查時に 明確な異常所見を示さないもの，(3)都市の一部，ことに 職種別には管理職に拈いて虚血性心疾患にもとづく変化 を合わせもつものがある（この数はごく少数である）. 以上の事実から脳卒中の分析に当っては, 地域, 職域を 考慮してその発生要因の検討を行う必要のあることを示 唆した. また，上記各集団における $2 \sim 4$ 年間の高血圧 管理の結果，(1)各地区とも 40〜69 才では管理前に比べ 管理開始後は脳卒中発生率は低下の傾向を示す. (2)管理 状況の良好な地区では不良な地区に比べて要管理者から の発生率が著明に低い。(3)検查時明確な異常所見を示さ ない者からの発生率は各地区とも大差なく,これらの発 生が目だつのは管理による要管理者からの脳卒中発生の. 減少がその一因と考えられる。

問：田崎義昭（東邦大阿部内科）管理後，脳卒中の 発生が減少しているが, 脳出血, 脳血栓の発生頻度はど う変化したか。

答：島本 喬 もっとも管理状況のよい八尾 A 地区で は脳出血は皆無, 八尾 B 地区では全脳卒中の 2 割, 能勢 地区では（もっとも管理状況が不良な地区） 6〜7 割が 脳出血で占められている，したがって，相対的には管理 状況のよいところで脳軟化の割合が多くなっている.

䓄問：三島博信 (洞爺協会病院) 管理職に打ける発作 


\section{一 $\quad$ 般}

例では心疾患によるものが多く，年令の若いものに多い ようにみられたのだが, 全体として年令的な発生頻度に 対する考按は行っていないのか.

答: 島本 喬 地域住民の症例と事業所復業員の症例 の年令的なずれを少なくするため, 年令を $40 〜 69$ 才に 限定して検討を行った. しかし, 事業所從業員の場合, 定年の関係もあって発作年令が若干若いはうにかたよる ことは否めない。

\section{3. 術後に脳血管障害を伴なった症例の臨床}

金山知新 玉熊正悦 中山真太郎 小泉澄彦

荷見秋彦 石山 賢 中野春雄(東大 石川外科) 林 四郎（信大 第 1 外科）

最近 10 年間に東大第 1 外科で手術が行われ術後脳血 管障害を合併した症例は, 胃疾患 12 , 四肢動脈閉塞 4, 肝腫瘍, 直腸癌, イレウス, ヘルニア, 総胆管結石各 1 の 21 例で入院患者の $0.2 \%$ にあたる. 術後 3 日以内に 発症したものが 9 例, 残りは 4 日ないし 10 日目の離床期 に発症した. 30 才代 1,50 才代 9,60 才代 5,70 才 代 4,80 才 2 例で循環器系に関する術前検査成績でも, 心房細動・左室肥大・ST-T 変化なぞの心電図異常 19 例, 動脈硬化症 15 例, 収縮期血圧 $160 \mathrm{mmHg}$ の高血 圧 9 例, 脳卒中の既往歴を有するもの 6 例, 認められ, これらの異常所見がいずれも認められないものは 2 例に すぎない. 次に初発臨床症状とその後の経過を比較する と，第 I 群：意識障害や嘴眠で始まり半身不随に陥った 7 例と, 第 II群：血圧上昇, 頭痛で始まりまもなく痙摹 発作, 意識消失をきたした 4 例は高い致命率を示し各群 とも1例を残して他は死亡している.これに反し第而群 : 言語障害で始まり咴眠, 半身不随にいたった 6 例と, 第IV群 : 不眠, 售妄に対し鎮静剂投与をうけて意識消失, 半身不随に陥った 4 例は比較的低い死亡率を示した，入 院中の発作が初回の 15 例中 9 例 $(60 \%)$, 過去に卒中 発作の既往歷を有するすの 6 例中 4 例 $(68 \%)$ 死亡した が，この致命率は佐々らが報告した一般の脳卒中の致命 率と大差ない. 剖検の行われた 9 例ではクモ膜下出血 4 例でもっとも多く, 脳内出血 3 例, 広汎な癌転移と矢状 静脈洞血栓症各 1 である. 卒中発作時間の明確な 15 例 中 11 例まで深夜から早朝にかけての安静時に出現して いることからも, 術後脳血管障害には血栓症が多い可能 性を想像させるが，剖検の結果や臨床診断は必ずしもそ れと一致しない，一般に手術後出現する脳血管障害は, 老令者に術後一過性に認められやすい急激な血圧上昇な
演題

$6: 109$

ぞー部の因子を除けばその予知ないし治療はきわめて困 難な現状であるが，最後に低分子 Dextran やステロイ ドなど, ショックの一般的治療で回復をみた 1 例につい てふれた。

質問：三島博信（洞蓈協会病院）わたくしども二, 三の経験をもっているが, その臨床症状では上下肢の機 能の比較的軽いものが多く, 痴呆化, 引つ病化傾向のよ うな精神障害を有するものが多いように思われるが。演 者の剖見例では一般の CVA と発作部位になにか違った 点がなかったかどうかお教えいただきたい．

答: 金山知新 剖検した 3 例の脳内出血については, とくに一般の発生部位との違いは認めない。

\section{4. 脳出血の発生機序に関する研究}

一高令者の前障外包出血について一

山村武夫 玉沢 昭 河原裕憲 金子弘(東菌大 病理) 村上恵一(慶大 相沢内科) 杉浦昌也 $<$ 内科 $>$

\section{嶋田裕之<病理>（東京都養育院）}

われわれは脳出血の成因を解明するため, 超軟 $\mathrm{X}$ 線 法その他に上る検索をつづけている. 今回は, 従来あま り注目されていない前障外包の出血を, 脳出血 65 例中 に8例経験し報告した.

前障外包部の血管構築をみると, 前障は中大脳動脈の 脳表枝である島動脈の実質内分枝によって養われ，外包 には前括よび中線状体動脈の末梢分枝が分布している. 前障外包の出血巣は，主として島動脈より分岐する髄質 動脈の領域に一致し，これを中心として島動脈の皮質下 動脈・前・中線状体動脈の末梢分布域に及んでいるが, 尾状核, レンズ核, 視床の前脳幹諸核は, 被殼の外線を 除いてよく保たれている.内包が直接侵されることはな く, 諸線維は出血により放線冠内包上部で遮断される.

今回経験した 8 例は, 70 才代 3 例, 50 才代 2 例, 40 才代 3 例で全例既往に高血圧を有し, 発症時血圧も高く, 末期まで高血圧を持続している. このうち， 70 才代の 3 例は壮年例とその臨床像を異にし, 発症当初の意識障 害が軽度であるか, または経過中緩解期があり, 死亡ま での期間が長く，脳軟化症と思わせる経過をとっている。 すなわち, 高令者の前障外包出血には, 既往に高血圧が あり, 発症後脳軟化型の経過をとりながら高血圧を持続 するという特徵がみられた. 血管構築の面からみて前障 外包は脳軟化をきたしやすい部分であり，ことに高令者 のこの部の出血は, 臨床症状とあわせ考元るとき, 通例 の脳出血と発生機序を異にし, 脳軟化が先行して二次的 
に出血が加わったものではないかと推定している．な拉 今後症例を重ねて検討したい.

135. 血圧および血管透過性面からみた 脳血栓の発病機序に関する一見解

河野 靖 遠藤 久 矢野正司

（市立富士宮総合病院 内科）

新 城之介 吉村正治 和田行一 赫 彰郎 日高隆徳 大中道 淳 瀬田健一

(日本医科大学 新 内科)

臨床的に重要な血圧と脳血管障害との関係についてみ ると, 従来より脳出血例に高血圧者が多く, 脳血栓では ほとんど常に血圧が低い事実が広く認められていた。し かるに最近, Kendell らは血圧の低下による脳硬塞の発 病はあまり重視すべきでなく，むしろ血圧の上昇が一過 性脳虚血発作の誘因であろうと報告している．わたくし どもは脳血管障害例に打ける血圧と血管透過性とについ て検索して，脳血栓に打いても血圧が上昇している例が 少なくなく，脳出血および脳血栓ではともに上肢毛細血 管透過性障害が増強している結果をえた。

脳血栓の発病機序は複雑であるが，血圧が上昇し脳血 管の受動的収縮が起こり，一定の血圧值までは脳血流調 節機能が働くが，著しい昇圧のため血流調節障害が発現 し, 灌流圧が亢進して脳血流障害が増強して低酸素状態 となり，交感神経が興奮して血管氫尜が起こるといわれ ている. かような脳血流および血管障害が存在する状態 に打いて,さらに四肢毛細血管透過减少性障害が加わっ た場合には，脳血管機能障害の著しい増悪が起こり，高 血圧性，血管痙攣性脳血栓の発病の一因をなすものと考 える。

留問：美原 恒（神戸大第 1 生理）拈話の中の, 水分 漏出量はどのようにして測られたものか伺いたい。

答: 河野 靖 Landis-Fujita's Congestion method.

\section{6. 脳血管損筑の成因に関する研究（第 4 報）}

永井忠之 村上元孝 関本 博 安村昭芳

瀬尾迪夫 竹内 功（金沢大 村上内科）

われわれは脳血管損傷発症の一つの誘因として，腎皮 質中に含まれる血管透過性六進物質をとりあげ，感作赤 血球凝集阻止反応を使用することにより流血中の本物質 を免疫学的方法により定量してきた．臨床検索成績から も本物質が種々の血管損傷の発現に重要な役割を演じて いることを明らかにすることができた．
6 巻 2 号 (1969:3)

今回社会祉福法人 “陽風園” 收容者を対象に過去 3 力 年間にわたり，経過を追跡しえた 200 例について凝集阻 止価の病態生化学的意義について検討を加えた.

凝集阻止価の高值を示したもの 86 例中, 死亡者は 28 例， $32.5 \%$ ，凝集阻止価の低值を示したもの 114 例中死 亡者は 14 例で $12.3 \%$ であり両者の間には推計学的に有 意の差が認められた，死因別では凝集阻止価の高值を示 したものでは 28 例中 19 例が脳血管損傷であり，低值を 示したものの死因は 14 例中 10 例までが，血管損傷に 関係ない疾病であった．剖検にょって死因のはっきりし た例での阻止価との対比でも同様の結果がえられている。

血圧との関係でも死亡例では凝集阻止価が高く血圧の 高、例が多く，生存例では凝集阻止価が低く血圧も低い 例が多かった，心電図所見とのあいだにも心電図に所見 があり凝集阻止価の高いものに死亡例が多く，眼底所見 との間にも死亡者では阻止価が高く $\mathrm{kW}$ III 度以上のも のが多かった。

腎皮質中に含まれる血管透過性六進物質は脳血管損傷 の発現に重要な役割を果たし，その予後にも影響する所 が大きいと思われる成績をえた。

\section{7. 脳卒中の要因解析に関する計量医学的 考察 (VI)}

福井 洸 高橋晄正 大島良雄

（東大 物療内科） 龟山正邦（浴風会病院）

昨年予報したごとく，脳卒中の発作後できるだけ早期 に病変や部位を診断するための試みとして，浴風園の症 例脳出血 63 例, 脳硬塞 40 例について, 発症後 24 時 間目の臨床症状 36 項目によって計量診断を行なった。 診断すべき部位は前大脳動脈領域, 中大脳動脈領域, 基 底核部, 視床, 脳幹, 小脳, 蜘網膜の 7 部位, 病変は出 血と硬塞の計 13 のカテゴリーである.

診断の方法は尤度法を用いた。

〔結果〕最尤位のもののみによる点推定では正診率 $91.2 \%$ ，例数の少ない部位を除いた中大脳動脈，基底核， 視床の 3 部位での正診率は 83 例中 74 例 $89.1 \%$, 病変 を問わず部位のみを診断すれば 103 例で $92.2 \%$ であっ た.

また比度 10 倍までのものを含む区間推定では，正診 率 $95.1 \%$ に向上し，保留率は $11.6 \%$ であった.

〔考按】(1)以上の結果から計量診断による信頼度をみ ると, 中大脳動脈領域の硬塞では $21 / 22$ 例 $95.4 \%$, 基 底核の出血では $27 / 28$ 例 $96.4 \%$, 視床の出血では $17 /$ 


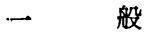

19 例 89.4\% であるが, 基底核の硬塞は $9 / 14$ 例 64.2 \%と低い.これは基底核と中大脳動脈領域の硬塞は症状 が類似し，診断しがたいためである.

(2)診断に使用した 36 項目の情報量をみてみると, 発 作後の意識, 呼吸, 血圧, 発熱, 呼吸, 麻疸の状態など は情報量大きく, 既往歷, 発作の起り方, 心電図所見, ミオクローヌス, 麻瘏側のトーヌスなどは情報量が少な かった．これら情報量の少ない項目を一つずつ除外し， 残りの 22 項目での診断の情報をみると正診率は $84.4 \%$ でやや低下するのみであるが, 区間推定では正診率 96.1 \%で，保留率 $30.1 \%$ と保留診断が著増した。

(3) 36 項目の症状の相互の相関を調べると, 発作後の 呼吸と意識障害, 対光反応, また麻㾇の部分と程度, 意 識障害, 対光反応などが比較的相関が高いことがわかっ た. 今後は例数を增すとともに, 情報量, 相関の高い項 目をも考慮に入れて正確を期したい。

\section{8. 脳卒中の成因に関する研究}

一白血球成分の血管透過性六進因子(第 2 報 $)$ 村上元孝 関本 博 竹越忠美 竹内 功

稲垣 修 岩城紀男（金沢大 村上内科）

白血球の成分の分画中に実験病理学的に脳血管の破綻 をきたしうる物質のあることを先の本学会で報告したが, 今回はさらにそれらの免疫学的な特徵を主に, 一部では 臨床例について検討を加光， 2,3 知見を党たので報告 する.

先にわれわれが報告した方法を若干変更し白血球成分 の lysosome 打よび microsome 分画を分離した。これ らの分画は微少顆粒成分で核に親和性の強いチオニンに よく染まる. 抗血清の調整にはこのまま antigen として 使用, 生物活性の測定には超音波にかけ可溶性とした.

定法に従い各分画の抗血清を調整, ouchterony で検 討を加えたが, 白血病性白血球成分とはその抗原性に若 干差異が認められた．螢光抗体法を用いて骨髄標本に螢 光染色を行ったところ白血球の成熟の度合により, 各細 胞成分の抗原性にかなりの差が認められた.

老人ホームでの漂瘕を有する患者の剖検例に㕠々死因 が比較的新鮮な脳血管障害につながるところから, 褯癜 部の瘡液について免疫学的な考察を加えた. Ouchterony では各抗血清とのあいだに $3 \sim 4$ 本の沈降帯を認め,こ ういった白血球崩壊産物が大量に流血中に流れ込み, 脳 血管障害を惹起せしめ5る可能性る考えられる. 白血球 の崩罟産物で感作したひとO型赤血球を用い, ここれらの
演題

$6: 111$

患者の感作赤血球凝集阻止反応を試みたが，数少ない症 例ではあるがかなり変化のある結果がえられた．この意 味づけについては改めて報告する予定である.

留問：脇坂行一（京大 第 1 内科）

白血球の血管壁透過性六進物質は, ぞの種類の白血球 に含まれているか，また脳卒中の発作前後で，血清中の 血管壁透過性㐫進物質に量的に差があるか.

答 岩城紀男 対象は主に顆粒球である.わたくしど もは，リンパ球を可及的に取除いた顆粒球を主に取扱っ ているのであるが，多少まだ contamination の懸念があ るので, あえて顆粒球といら言葉を使うのを避けた。

答: 関本 博 発作直後例については, 先のスライド に示しました例の中に入っている. その例の感作赤血球 凝集阻止反応の高值のものるスライドの実例で打見せし たごとしであるが, 発作との詳細な関連については，さ らに予後の検討が必要である.

討論：脇坂行一（京大 第 1 内科）以上 5 題を通じて, 脳出血の年令的, 部位的差異と脳血管構築との関係, 脳 出血, 脳血栓と血圧, 血管壁透過性, 血管攣縮との関係, 腎皮質および白血球中に含まれる血管壁透過性亢進物質 の脳血管損傷に対する病態生理学的意義が検討せられ， また脳卒中の臨床症状と病理解剖学的所見との対比につ いて，式度法による計量的考察が陚みられた．脳血管障 害の発生には, 脳血管の解剖学的变化, 血圧のほかに, 血管壁透過性穴進の面からみた病態生理学的研究も必要 なことが強調されたと思う。

\section{9. 脳出血モテルとしての脳内ハララフィン} 塊作成時の䯣液線溶活性について 藤井忠男 光野孝雄 <光野外科 $>$ 美原 恒 松尾 理 $<$ 第 1 生理 $>$

（神戸大）

さきに，著者らは脳出血のモデル実験として，1ヌの 脳内に自家血を注入し, 実験的に脳内血腫をつくり, そ の髄液の線溶活性を測定, 線溶活性が亢進した例では短 時間に死亡し, 線溶活性の軽度ないし方進を示さない例 では長期間生存すること，また，線溶活性の充進を示し た例でも，抗プラスミン物質の投与により，明らかに致 死率を改善し5ることを報告した。

今回，われわれは血液の代りにパラフィンを注入し， このパラフィン量と, 髄液の線溶活性および，その致死 率について追究した。

その結果, 頭蓋内に注入されたパラフィン塊が, 硬膜 
下，ないしは脳室内に注入された場合には，その量がか なり大量 (1260mg) であったにもかかわらず，髄液の 線溶活性は充進を示さずイヌは 5 日間以上生存を示した。

これに対しパラフィン塊が, 脳実質内に存在し, 脳実 質組織を破壊した量が大きい場合には, 髄液の線溶活性 は急激に上昇し, 短時間にイヌは死亡した。

以上の事実から脳実質内にみられたパラフィン量は, 脳実質組織の破壊の程度を示すものと考劣るし，このパ ラフィン量, 云いかえれば, 脳実質組織を圧排した量, あるいは, 脳実質の破壊量が髄液線溶活性の上昇とかな り密接な相関関係を有するるのと考えられる.

また, 臨床的には, 出血の結果, つくられた血腫の pace occupying lesion により, 脳血腫周辺の組織線溶 活性が充進し, 血腫周辺からの出血が起こり, その結果, その血腫の増大をおこし，これが死亡に結びついていく と考えられる.

買問：五島雄一郎（慶大相沢内科）髄液のプラスミン 活性の増加は, 病巣部のプラスミンが髄液中にはいった ものか, 髄液中において活性されたものか.

答: 美原 恒 髄液の線溶活性は流入した血液による ものとは思われない.なぜならば(1)脳血腫周辺に正常に はみられない遊離アクチベーターの出現が捛こること. (2)髄液の線溶活性が光進しても, 血液線溶は, とくに, みるべき上昇を示していない（3髄液中の出血量を測っ て, 髄液の線溶活性にひきつづいて, 出血が起こってく る. 実験的に髄液中にプラスミンを注入すると,つづい て出血がおこることも経験している.

答 : 藤井忠男 パラフィン塊が脳室内に穿破した場合 の髄液の線溶活性については先程のスライドにも示した よ5に, 穿破量線溶活性との間には相関関係は認められ ない.

むしろ, 脳実質の破壊量により檤液の線溶活性の上昇 が起るものであり, 脳実質の組織アクチベーター髄液内 移行が考えられる。

追加：美原 博(畄血管研究所) Space occupying mass であるなら，あながち血腫でなくてもプラスミン活性が 亢進することは興味深い．わたくしは 506 例の血中プラ スミンを測定し，本学会で報告したが，短い経過で死亡 する脳内大出血では著しいプラスミン活性上昇をみる場 合が多かったが，治瘾例では上昇をみないすのが多かっ た。目下出血と軟化の血液は髉液中のプラスミンを同時 測定している陳旧例では，いずれも活性の六進を認め ないが，新鮮例では血中プラスミン值の上昇を認めない
6 巻 2 号 $(1969: 3)$

ものに，髄液プラスミン活性の上昇を見るものがある. また昨年本学会に報告したが，脳出血手術例の血腫プラ スミン上昇していたものに術後再出血が多いことも本発 表と考え合せ，興味がある.

\section{0. 老年者脳血管障害例の出血性素因ならびに} 凝血因子に及ぼす各種薬郕の影響について

新 城之介 吉村正治 和田行一 赫 彰郎 日高隆徳 瀬田健一 酒井 久

（日医大 新 内科）

河野 靖 矢野正司

（富士宮市立病院 内科）

東京都養育院東村山分院在住の老年高血圧者 13 名, 脳動脈硬化症 8 名, 脳卒中後遺症 7 名の 28 症例を対象 として塩酸パパベリン $(0.3 \mathrm{~g} /$ 日) , ニコチン酸 $(150 \mathrm{mg} /$ 日), バリダーゼ内服錠 ( 4 錠/日)，サイクロナミン (1.5 $\mathrm{g} /$ 日), を夫々 7 例宛 4 週間単独投与し使用前, 使用後 1，2，3，4 週について上肢毛細血管抵抗 (Rumpel-Leede 法), 出血時間 (Duke 法), 凝血時間 (Lee-Wite 法), プロトロンビン活性（Quick 1段法），第 VII 因子活性

(Koller 法)を測定した.

塩酸パパベリンでは出血時間の短縮, プロトロビンお よび第VII因子活性の減少傾向を認め, ナイクリンでは軽 度であるが毛細血管抵抗を減弱せしめる例のあることを 経験し，プロトロビン活性，第VII因子活性の減少傾向を きたすことを認めた．またバリダーゼでは凝血時間が多 少短縮をきたすが，他の因子に影響なく，サイクロナミ ンでは出血時間の短縮，毛細血管抵抗の改善，プロトロ ビン活性の増加傾向をみとめた。

\section{1. 高年者脳血管障害における線溶能}

土屋博文 原田歳久 道川建一 村上恵一

大川日出夫 野口八郎 (永寿総合病院 内科)

高年者脳血管障害は若年のそれとやや異なる樣相を呈 するものが多いので, その発症・経過と線溶能・プラス ミン活性との関係を解明しょうとした。

線溶能の測定には血漿塊溶解時間, ストレプトキナー ゼ活性化プラスミン・フィブリノーゲン量・フィブリン 平板法を用いた.

高令群でも，線溶能の傾向は，若年者を含む一般脳出 血・脳血栓群のそれぞれの傾向と本質的には同様であっ た.

つまり, Ratnoff 氏法によれば, 脳血栓群では 4 日な 


\section{一 般}

いし 9 日の溶解日数を示し, これに対し脳出血群では 4 日拉よび3 日の溶解日数を示した.

さらにフィブリノーゲン量については, 脳出血群では 減少傾向を示す例があり, 脳血栓群では増量をみる例が 多く, しかもフィブリノーゲンの著明な増量は予後不良 の脳血栓患者群に多かった。

ユーグロブリン溶解面積と予後とを検討すると, 脳血 栓群のうち死亡例では発症数日後より線溶能の低下が著 明となり, 生存例では発症後 1 時溶解面積の減少を示し たのち，経過ととに線溶能の上昇を認めた.

最後に, 高令者に多い多発性脳軟化巣の問題, また老 人脳出血患者にしばしばみられる出血巣の拡大機転に関 し, 線溶能の低下あるいは元進がその進展過程に関与し ているであろうことが示唆された.

澌問：松尾 理（神戸大 第 1 生理）われわれは，長 年にわたって E-aminocaproicacid ならびに, transformed-aminomethylcyclohexancaproic acid について研究 してきた.

脸血栓症に関しては，われわれは，単に antiplasmin 活性が上昇するがゆえに，生じるとは考えてはいない. Anti-plasmin 物質投与動物にいまだに脳血栓症をえて いない. また脳軟化症に関して, われわれの臨床例では, 早期に死亡する群では, 異常に plasmin 活性が立進し ている.これは, 先生の発言と, 相反するが, 先生はい かに考えられるか

答：土屋博文 脳血栓の発症に関しては線溶能のほか 各種の因子が考劣られるが, 疾病の経過, 予後, 殊に多 発性軟化巣の進展等に線溶能が， ある程度の影響がある と考えている.

答 : 村上恵一 脳血管障害の発生機転は種々の因子が 関与するものであり，いずれかの一者のみが成因となる ことはむしろまれであろう，線溶能の変動の影響も, 先 行する血管傷害の存在を当然考慮すべきところで, 既往 の血管病変の状態如何により変動する. すなわち両者の 相関が病因として意義のあるものと解される.

\section{2. 脳卒中の研究（第 51 報）}

一血液凝固能について一

楠 亮二 勝木司馬之助 原 昌徳 大園敬子 (九大 勝木内科)

藤島博明 (九州学災病院 内科)

昭和 37 年以来九大勝木内科に入院した脳卒中患者約 250例 について血液凝固能を検索し次の結果をえた.
演題

$6: 113$

(1)脳卒中においては，血漿トプ活性，フィブリノーゲ ン, ユーグロブリン溶解時間, プラスミン活性, 血小板 粘着凝集率に対照群と有意差がみられた. (2)これらの凝 固能の変動は脳出血と脳血栓とのあいだに本質的な相違 はなく，その異常の度合が脳出血の方に強い傾向がみら れた. (3これ等の凝固能の変動は発作後 1 週乃至 1 力月 に最高を示すものが多く, 以後次第に正常值に近づくも の（T.G.T，フィブリノーゲン血小板粘着能）および 3 カ月以上も向有意の高值を示すもの（PTT, 血小板凝集 能）がある. (4)この最後の群が脳血栓の成因にもっとも 関係が深い重要な因子であろうと考えている.

質問 - 討論 : 村上恵一（慶大 相沢内科）(1)経過良好 例と不良例とに分けて測定值を整理された成績があれば， お示しいただきたい。

(2)われわの成績ではすでに発表を重ねたとおり, 脸 出血, 脳血栓それぞれにつき, また経過の良否により異 なる結果である.病型との関連でことに注意すべき点は, 病理的に純出血型, 純軟化型, 出血, 軟化の両者が発症 ならびに経過上たがいに関連をもつ型があり，成績をみ る場合はこれについて考慮を要するものである.

答: 楠 亮二 (1われわれも, 予後のわるいものは, 血漿トプ活性, フィブリノーゲンの増量が著しいことを 認めている. プラスミン活性についても, 同様の傾向が みられる様である。

(2)病理学的に脳出血, 脳軟化のあいだには基礎的に共 通の病変があるのではないかという考えに同意である。 したがって, 血液凝固学的にも本質的な差はなく, 症例 に応じていろいろ修飾されるものと考える.

翼問 : 五島雄一郎 (慶大相沢内科) 発作直後の脳出血 ではプラスミン活性が亢進し，フィブリノゲンの減少を 認める例が多いが，演者の成績で脳出血でプラスミ活性 が亢進しフィブリシゲンが増加している矛盾すると思う がどうか.

答: 楠 亮二 われわれが多数例について検索し, 推 計学的に処理した結果では上述のとおりである. 脳出血 のときにみられる程度のプラスミン活性の元進で, 実際 に血漿フィブリノーゲンにどれほどの影響を与えるか疑 問である。

\section{3. 脳血管性潭害の酵素学的研究（第 5 報）}

浜田康治 坂元藤雄 大勝洋祐 森園隆一 （鹿览島大 蓩島分院; 金久内科）

わたくしどすは昨年の本学会で, 実験的脳実質損傷な 
$6: 114$

日本老年医学会倠誌

らびに脳硬塞のさい，血清 CPK 活性值の上昇すること を発表し，ついで日循総会その他において，臨床例につ いて血清の経時的変動のパターンをば論じた．今回は次 の点についてのべたい.

(1) 発作後 1 力月以内までに観察した脳卒中 44 例の 血清 CPK の変動を経時的にプロットした.

(2) 脳血栓症では, 発作後 $1 \sim 3$ 日に血清 $\mathrm{CPK}$ は上 昇し, その後一旦低下し，2 週間目頃にやや上昇するが， その平均值は最大值を示す $2 \sim 3$ 日目です 17.9 単位で あった。

(3) 脳出血では発作後 1 日目 $46.5,2 \sim 3$ 日目 81.1 , 4〜7 日目, 34.1 単位とその平均值は著しく正常値をこ えた。

(4) クモ膜下出血では 1 3 週目に平均值は正常值を こえた

(5) 3 例に再発作ないしは症状の増悪でみた. 5 ち 2 例に症状の増悪する以前に血清 CPK の上昇をみた。

(6) 5ち 1 例はクモ膜下出血で第 12 病日に完全片麻 痺を来したが, 第 10 病日に CPK は 64 単位であった. 他の脳血栓症 (疑) で発作後 49 時間目に完全片麻瘦へ の移行と昏睡をきたしたが，その 1 時間前に CPK は 56 単位を示した。

(7)これらの CPK の上昇が, 症状の増悪に直接関係 するものか否かについて, 他の症例と比較しながら論じ たが，今回はただその事実を報告するにとどめ，さらに 症例を加えて検討をすすめたい。

\section{4. 年令別よりみた脳血管袥害の臨床 病理学的研究}

一脳出血, 脳血栓の病巣部位を中心として一 平井修司 相沢豊三 五島雄一郎 荒木五郎

村上恵一 佐藤信久（慶大 相沢内科） 山村武夫（東武大 病理）

脳出血 34 例, 脳血栓 69 例の病巣部位を中心に検討し た結果, 脳出血, 脳血栓ともに, 内包基底核部に病巣の あるものがもっとも多かった。これは従来の諸家の報告 と一致する. 次に年令別でみると, 原発性橋出血は, 60 才未満の群で 6 例みられ， 60 才以上の高令者ではみら れなかったこと, 高令者出血例には, 既往に脳軟化の発 作を有した例が多かったこと, 主幹動脈の血栓例は, 各 年令別の症例数との対比では, 60 才未満の群に頻度が 高かったことなどの傾向がみられた．われわれの成績は， 未だ症例数にとはしく，統計的に結論をだすには不十分
6 巻 2 号 (1969:3)

ではあるが，主幹動脈の血栓例は 10 例（脸底動脈閉塞 症 4 例, 内頸動脈血栓 1 例, 前大脳動脈血柽 1 例, 中大 脳動脈血栓 2 例, 後大脳動脈血栓 2 例) あり,これらは 60 才未満の群に頻度が高く, 症状も重篤で, ほとんど の例が脳出血と誤診されていた. 診断上注意すべきこと と考える.

填問：三島博信（洞爺協会病院）ただいまの発表で年 令別, とくに 49 才以下のものと, 50 才以上のものとの あいだに病巣の部位が異なるという点は興味あるものと 思われる.わたくしどもの臨床所見の検討でも両者のあ いだに若干の差があるように思われるからである.

もし演者が生前の臨床所見を検討していればお気附の 点を京いたい。

答：平井脩司（1) 年令別で，脳血管障害の臨床症状 に違いがあるかどうかという御質問であるが，臨床症状 を比較する場合, 病巣部位, 大きさが関係するし，また 症例数も，それらを考虑して比較するには十分でないの で，いまだ行っていないから，敃答えできない。

(2) わたくしどもの年令別に病巣部位を検討したねら いは, 主幹動脈の血栓例, これは脳出血と誤診される case が多いことより，これらが，どの年令に多いかとい うことをみることにあったわけである. その他, 主幹動 脈の血栓例と, lacune を有するような主として脳動脈の 分枝の閉塞のみがみられたような症例とのあいだに，な にか相違があるかどうか, 今後症例を重ねて, 追及して いこうと思っている.

答 : 村上恵一 脳軟化群の臨床的差異として, 比較的 若年で太い血管の傾害をみる群については急速な経過を 示す例の率が多く, 高令で細い血管の範囲に主に病変を みる群では経過が遷延する，また，高令者で小病巣の多 発をみる例では精神症状が前景に立つことなどについて はすでに発表した。ただし，臨床像は形態的脳または脳 血管病変にのみ厳密に対応するものではなく, 形態的変 化に機能的障害すなわち血行動態の变動などが重なって できあがるるのである。

\section{5. 脳の血管陣害の病理学的研究 (第 5 報)}

一とくに末梢循環系の変化を中心にして一 佐藤洋一 山口裕敬 新 城之介<新内科 $>$ 鈴木恒道 矢島権入 $<$ 第 1 病理 $>$ (日医大) われわれは, 脳血管障害を病理形態学的立場より解析 しているが, 今回は直径 $30 \mu$ 以下の細動脈と, 直径 300 $\mu$ から $50 \mu$ までの中小型系動脈の变化を比較検討する 


\section{一 般}

とともに, 剖検例の脳血管变化を電顕的に観察し得る可 能性についても, 若干の方法論的検索を試みた。

〔材料および方法]剖検例上り, 肉眼的に脳出血脳軟 化の認められなかった 332 例を非病变群とし，対照とし て脳出血 54 例, 脳軟化 34 例を病变群とした. 検索方 法は脳内各部より薄切切片を作り一部は光顕的に，一部 は電顕的に包理を行いPAM 染色を中心に観察した.

〔成績〕細動脈硬化は, 若年より中小型系動脈硬化に比 し高頻度に認められた。しかし 50 才を移行期とし中-小 型動脈の中膜硬化症が細動脈硬化に比し優位の立場をし めるょうになった．次に細小動脈と血圧との関係である が, 高血圧群は一般に硬化強く, 高年者では病変群との あいだに中膜および内膜に多少の優位の差が認められた ので本質的には变りなかった．一方細動脈血管障害型式 を次の 4 型に分け検索した. すなわち I 型：内被細胞腫 大, 基底膜肥厚, 中膜筋線維腫大, II 型 : 筋線維の変性, III型：膠原線維の増生, 中膜線維化, IV型：Dysorie を主 とする特殊変化である. 以上の結果, 若年では I II 型, 中年では II III型, 老年ではIIIIV型が高頻度に認められた. 結論ならびに考按 : われわれは脳の細小動脈を年令, 血 圧の面から追求した. すなわち, 脳の動脈硬化は細動脈 血管障害を基盤とする末梢循環障害の結果, 逆行性内圧 亢進が中一小型系動脈壁に作用し，さらに中枢からの内 圧六進を受けその硬化性病変をなお一相強めるものと思 われる. 一方われわれは, 剖検例のパラフィン切片の検 索のみならず, semi-urtra-thin-section 法および電顕的 観察を行い, これらが死後変化, その他の条件を考慮に 入れなければならないにせよ, 細小血管の病理学的検索 にきわめて，有力な手段となりらることを明らかにした。

\section{6. 老年者群ならびに若年者群の 椎骨脑底動脈腯㩍不全の瀶床 について}

$\begin{array}{llllr}\text { 門倉 } & \text { 辰夫 } & \text { 桂 } & \text { 武 } & \text { 永積 惇 } \\ \text { 山口 } & \text { 裕敬 } & \text { 花島 } & \text { 浩 } & \text { 高橋 信次 } \\ \text { 木村 俊三 } & \text { 和田 } & \text { 行一 新 城之介 }\end{array}$

（日医大 新 内科）

われわれは，椎骨脳底動脈循環不全症状を呈した患者 を老年者群と若年者群とに分けて, 両群の臨床症状なら びにこれら症状の頻度, 椎骨動脈写所見について検討し， さらに臨床症状と椎骨動脈写所見との関係を対比してみ た. 老年者群は 60 才以上, 若年者群は 35 才以下とし て，40才代，50才代の患者は除外した. 症例数は老年
演題

$6: 115$

者群 12 例, その年令は 60 才から 78 才, 若年者群 14 例，之の年令は 21 才から 35 才であった．臨床症状と しては, 老年者, 若年者ともに, めまい, 頭痛・頭重が 必発し, 次に耳鳴, 歩行障害, 悪心 - 嘔吐, 眼振, 知覚 障害が多く認められ, 老年者群で耳鳴, 歩行障害が若年 者群で屃こり, 眼振, 知覚障害がやや多く認められた. 椎骨動脈写所見としては, 老年者群に打いては, 管径不 同, 蛇行, 狭細等の動脈硬化によると思われる所見が, 椎骨動脈領域, 脳底動脈領域および後大脳動脈領域のそ れぞれに高頻度に認められるに対し，若年者群では同様 の所見を示するのる少なくないが, 閉塞様所見, 走行異 常などの変化があることを認めた。これらの所見から臨 床症状では老年者と若年者では明らかな差はないが, 血 管写に打いては，老年者は殆ど全例が動脈硬化性変化に よるものに対して，若年者では血管奇型などによるもの も少なくないものと考觉る.

严問 : 三島博信（洞爺協会病院）頸椎骨軟骨症でも， 椎骨動脈の血行不全を起こし, やはり, 頭痛, めまい, 眩暈, 視力障害などの症状を起してくるが, 演者の症例 では頸椎椎骨, 軟骨の変化のあったものであったか（わ たくしどもの検査ではその頻度はかなり高い).

答: 門倉辰夫 後頭骨環椎㾙合の症例, 第 2 頸椎異常 可動性のある症例，むち打ち症候群等で，われわれも， めまい, 頭痛・頭重等の症状を出現した症を経験したが, 今回の報告には含めなかった.

筫問：田崎義昭（東邦大 阿部内科）若年者の椎骨, 脳底循環不全症例が多いように思うが，かかる症例では 診断規準に問題がある. 若年者群の合併症は, いかなる ものであったか.

答: 門倉辰夫 われわれの症例では, 若年者群の合併 症は，ほとんぞ認められなかった。

\section{7. 脳卒中の弨音波診断法}

-133 症の成績を中心として一 斎木 䈆 古川公一郎 金谷春之 （岩手医大 金谷外科）

脳卒中急性期患者の診断については, 詳細な神経学的 検查に各種補助診断を使用しても脳出血と脳硬塞の鑑別 は困難な症例がある. 特に外科的治療ではそれを術前に 確定し, 血腫局在, 大きさ等を把握する必要がある. こ れらを明らかにする目的で, 昭和 36 年以来超音波診断 法を用い, 基整的, 臨床的実験を行ない, 脳内血腫から の反射波である多䊂性の血腫エコーを検出した．この多 
棘性エコーを検出することによって脳出血と確定診断を 行ない，脳硬塞と鑑別できることはすでに発表してきた が，その後の症例を加え優れた成績を収めている.

脳卒中症例は 133 例であり, 高血圧性脳出血 81 例中, 正中線エコー（以下 M.E.）の偏位は 59 例 (72\%), 多欶性の血腫エコー（以下 H.E.）は 71 例 (88\%) に 認め, 両者綜合すると 72 例 (89\%) の成績である. 脳 硬塞は ME 偏位を認めたものは 38 例中 2 例, 33 例 (87 \%) は何等異常所見を認めなかった. クモ膜下出血 14 例中 2 例に M.E. の偏位を認め, 全例に H. E. は認め られない.この結果からの偏位を認めたものはほとんど 脸出血であるが, 偏位のないものでは $30 \%$ 近くに脳出 血の症例である.

脳出血であって超音波検査で何等異常所見を認めない ものは 9 例 $(7 \%)$ で，この5ち特に天幕上出血は 2 例 のみである.

また天幕上出血の血腫部位を Scheinker の分類に彷 ↔, 外側型, 内側型, 混合型と分類すると, 外側型は $\mathrm{ME}$ と $\mathrm{HE}$ は完全に分離し, 直接波から $\mathrm{ME}$ までの距離に 対する $\mathrm{HE}$ の距離の比率は $25 \%$ 以上であり, 視床表面 エコーより外側に HE のあるものである.

以上徒来の鑑別診断とはまったく別の立場から簡便, 正確に数量的評価で鑑別し, 出血の予後の推定をも行な っている.

問：美原 博（脳血管研 美原記念病院）脳軟化で， シフトのあった 2 例の, 閉塞部位は.

答: 斎木 䉷 脳硬塞例に ME の偏位を認めるが, 1 例は中大脳動脈の起始部で閉塞し, 他の 1 例は脳血管学 上閉塞部位ははっきりしない.いずれも脳浮腫によるも のと考えている.

\section{Retrospective にみた脳卒中死亡例の}

\section{眼底カメラ像}

山形敞一 鈴木仁一 佐々木陸郎

長谷川康幸 阿部秀逸 $<$ 山形内科 $>$

桑島治三郎 $<$ 長町分院 眼科 $>$

(東北大学)

われわれは宮城県心臓血管病予防協会と共同で, 昭和 40`年より 42 年までの間に，県内一般住民高血圧検診に おいて, 13,598 例に眼底カメラ撮影を実施してきた. その中, 脳血管障害で死亡したもの 197 例について検診 時の眼底写真所見を retrospective に検討した. 眼底写 真の判定は, 東北大式判定法と厚生省科学研究班の分類,
6 巻 2 号 $(1969: 3)$

$\mathrm{KW}$ 分類を併用しているが，今回の発表には $\mathrm{KW}$ 分類 を使用した，死亡例の診断名は，主として人口動態調査 票の死因によったが，それを確認するため，死亡時の様 相を遺族より聴取し, 文部省脳卒中研究班による脳血管 障害診断基準に従って病名を推定した. その結果, 脳卒 中死例ではいづれの判定法によっても眼底所見の重症度 と脳卒中死亡率とは必ずしも平行せず, 軽度変化例にも 相当数の死亡例がみられ，従来の判定基準では予後を予 測できない症例が多かったので, 眼底写真により網膜動 脈管径ならびに管径比を測定し，死亡例との関係を検討 してみたとの結果，上耳側動脈では，健康例の管径 $0.080 \mathrm{~mm}$ 以上に対し, 死亡例では $0.079 \mathrm{~mm}$ 以下のも のが大部分を占め, 管径比も健康例の $70 \%$ 以上に対し, 死亡例では $69 \%$ 以下のものが多くみられた. 下耳側動 脈についても同様の傾向が認められた. また, 検診して から死亡するまでの期間が長いものより短かい期間で死 亡した例ほど動脈径の細いものが多くみられ, 管径比も 小さいものが多くみられる．静脈管径は動脈ほどの変化 はみられないが， KW 分類で高度の変化のあるものほ ぞ, やや太くなる傾向がみられた.

質問：荒木五郎（脳血管研究所 美原記念病院）われ われの成績では脳卒中のうちの脳出血において軽快例と 死亡例に眼底動脈血管の狭細の発現の程度および発生率 に有意の差があり, 脳軟化症では軽快例と死亡例に差が 殆どみられなかった．脳出血と脳軟化と区分した場合， 貴院では成績はどうなっているか.

答：阿部秀逸（東北大 山形内科）脳出血と脳硬塞で 死亡した症例のあいだに，血管径ならびに管径比に明ら かな差はみられなかったが, 脳出血例より脳硬塞例に, やや細い症例が多かった。

\section{9. 脳卒中の研究 (第 50 報)}

一脳血栓症例に対する Porteus 迷路テスト 成績の日米の比較一

岡山昌弘 勝木司馬之助 永江和久

吉沢僖教 後藤幾生 三好 甫 (九大 勝木内科)

Manfred J. Meier (ミネソタ大 精神神経科)

昭和 37 年以来わたくしどもはアメリカ・ミネソタ大 学との脳卒中の共同研究の一環として, 脳卒中患者に数 種の心理学的テストを行い, 比較してきたが, 今回は脳 血栓症例における Porteus 迷路テストの成績の日米の比 較を行った. 


\section{一 般}

日本 33 例, アメリカ 84 例の脳血栓症例を左半球障 害, 右半球障害, さらにそれぞれを軽症, 重症とに分け, それらの test age (最高は 17.0) を比較し, 日本例が すべての群において顕著に高い test age を示した.さ らに年令, 性, 教育年数, 知能指数, 病巣側, 障害程度 をマッチさせた日米それぞれ 23 例について比較したが， それぞれの test age は日本例 13.3, アメリカ・9.8 と 信頼度係数 0.001 で日本例が有意に高い test age を示 した.このよ5に6つの因子をマッチさせた例を日米比 較しても，なお日本例が高い test age を示したという ことは本テストにおける日本人の優位性を示すものと思 われる.

この優位性が生まれつきのものであるか，われわれの 漢字を用いる習慣によるものかは今後の問題であろう.

買問：上田 敏（東大病院リハビリテーションセンタ 一) (1) Proteus 迷路テストの正常日本人についての標 準化は行われているか.

(2) われわれの成績で WAIS の動作性テストは右半 球障害の重症例で全般的に得点が低いが， dexterity を 要求するものは左半球障害 (右片麻舫) でも低下するの で差が少なくなることをみた. 本テストは視空間的認知 と Proteus のどちらにより多く関係すると考えられるか.

答 : 岡山昌弘 今回の成績では右半球障害と左半球障 害で有意な変化は認められていませんが, Porteus の迷 路テストを他の CVA を含めた例をマトメた際, 右半球 障害側において，有意により低い test age が得られた点 からも, dexterity が本テストに拈いて大きい要素をあ るというより, visuospatial なものが大きく影響を与え ていると思われます。

\section{0. 脸卒中の研究（第 48 報）}

一脳血管性障害の脳波学的研究-

吉沢僖教 勝木司馬之助 後藤幾生 永江和久

岡山昌弘 三好 甫 $<$ 勝木内科 $>$

梅崎博敏 $<$ 神経内科 $>$ (九大)

昭和 37 年 3 月より昭和 42 年 9 月迄に九大勝木内科 に入院し, 脳波検査を施行した脳血栓 122 例, 脳出血 14 例について, (1)発症後 1 力月以内の脳波を比較する と脳血栓 85 例中, 正常は $27 \%$, 軽度異常 $31 \%$ と軽度 異常または正常群が多いのに対し, 脳出血 14 例では高 度異常 $71 \%$, 中等度異常 $14 \%$ と波の出現をみる高度異 常群がはるかに多く, 統計学的に $\delta$ 有意 $(P<0.001)$ で あった. (2)発病後 2 力月の臨床経過より著明改善をI 度,
演題

$6: 117$

改善 II 度, 不変または悪化をIII度, 死亡をIV度と定め発 病後 1〜3 カ月にとられた脳波所見との関係をみると, I 度, II 度の改善群には脳波変化が軽度または正常が多 く, III度, IV度の不変悪化, 死亡群では脳波が高度異常 でる波を含むものが多かった。 (3)経時的に脳波を取りそ の変化をみると，3 月迄に多くの改善がみられたが, 臨床的に予後のよいものほどよく改善を示す傾向がみら れ，予後の悪いものは脳波上 $\partial$ 波が残存することが多か った.

\section{1. 脳波上よりみた初老期以降の 経年現象（第 3 報）}

一特に循環系との関連について一 小沢英輔 平岩章好 小林太刀夫

(東大 第 4 内科)

われわれはこれまで山梨県白州町において脳卒中及び 心疾患の疫学的研究を行い, その一環として脳波記録を 行ってきたが, 脸波所見と循環器諸所見とから次の検討 を行った．すなわち，40 才以上の成人脳波の経年現象 をとくに脳波の基本周波数の徐波化と，脳波の pattern の 2 つ側面から, 加令に伴な 5 出現頻度の変化及びそ れらと循環器系所見との関連から次の知見をえた.

(1)徐波群出現率は加令とともに有意に増加した $(P<$ $0.05)$.

(2)眼底有所見者（KWII a 以上）に徐波化が強い.

(3)心電図・眼底共に所見のある者に徐波化の強い傾向 あがる.

(4)周波数不安定型は女性に有意に多く出現し，これも また加令とともに増加し，女性のみについてみると 54 才以下では明らかな傾向がみられなかったが，55 才以 上では血圧の高い群に多く出現する傾向がみられた．眼 底所見では KW II a 以上の群に多く出現した。

(5) Diffuse $\alpha$-pattern は男性に有意に多く出現し, こ れもまた加令とともに増加し，60 才以上で KWII 上の群に多くみられた。

以上より, 脳波上の軽微な徐波化が循環系の軽微な変 化を反映していることと推測され，脳波 pattern からみ ると性差がみられ, 循環器所見別にこの pattern の出現 率をみると，55才ないし 60 才を境として差がみられた ことは, 循環器系の脳波に及ぼす影響に年令差が存在す ることを想像させる。 


\section{2. 脳卒中の研究（第 47 報）}

一脳血管性障害の計数表による計量的鑑別診断一

池田寿雄 勝木司馬之助 広田安夫

尾前照雄 竹下司恭 中野昌弘 緒方 絢

(九大 勝木内科)

大屋善友（福岡市大屋病院）

脳血栓，脸出血及びクモ膜下出血の計量的鑑別診断を 剖検または手術によって確定診断された症例に基づく計 数表によって試みた. 九州大学病理学教室の剖検側より, 脳血管性障害発症後 2 週以内に当教室員による直接診察 を生前に受けていた 97 例（脳血栓 40 例，脳出血 46 例 およびクモ膜下出血 11 例) を選び，クモ膜下出血手術 後生存 3 例を加えた計 100 例を対象とし, 発症後 2 週以 内の臨床記録を 37 項目につき数值化した. 各項目で病 型別症候出現頻度を調查し，力イ自乗検定により $1 \%$ 以 下の危険率で有意に判定された 16 項目（病歴 4 ，一般 症状 - 神経症状 11, 臨床検查 1）を選び, 対数尤度法 に基づき計算を簡便化した Index を病型別に求め計数 表を作った. Index の算出方法は， $\mathrm{i}$ 項目 $\mathrm{j}$ 階級におけ る脸血栓, 脳出血, クモ膜下出血の症候出現率をそれぞ れ $P_{1}, P_{2}, P_{3}$, 脳血栓, 脳出血の Index を, $X i j, Y i j$ と するとき，

$$
X i j=\left\{10 \log _{10} P_{1}\right\}-\left\{10 \log _{10} P_{3}\right\}
$$$$
Y i j=\left\{10 \log _{10} P_{2}\right\}-\left\{10 \log _{10} P_{3}\right\}
$$

ただし \{ $\}$ の中の数值の小数点以下は 4 捨 5 入し， 整数化する. クモ膜下出血の Index は常に0である. 対象症例に拈ける正診率は本計数表 $94 \%$ (発症後 2 週 内の資料で)，臨床診断 $78 \%$ (剖検申込時) で，計量診 断が優っていた.

\section{3. 脳卒中の研究（第 45 報）} 一脳硬塞における年令的因子の意義一 尾前照雄 勝木司馬之助 武谷 溶 西丸雄也 山口武典 岡部信彦 木元克治 西野 康 (九大 勝木内科)

発病後 1 力月以内にわれわれの内科に入院した脳血栓 (非塞栓性, 非出血性脳硬塞) 123 例について, 脳動脈 写所見, 心電図所見, 蛋白尿, 高血圧および糖录病の予 後に拈ける意義を高令者（65 才以上， 45 例）と非高令 者 (65 才未満, 78 例) に分けて検討した. 予後は発病 後 2 力月以内の臨床経過から好転群 (87 例) と然らざ る群 (不変, 悪化および死亡) (36 例) とした.

(1) 高令者は 27 例 $(60 \%)$, 非高令者は 60 例（77
\%)が好転した。

(2) 脳動脈写によって頭蓋の内外を問わず内径 $25 \%$ 以上の狭窄ある症例は, しからざる症例よりも明らかに 予後がわるく, 後者では $90 \%$ 以上の症例が好転してい るに反し，前者では非高令者 69\%，高令者 65\% が好 転したに過きない. 内径 $75 \%$ 以上の狭窄を示す症例の 好転率は, 非高令者 45\%, 高令者 $0 \%$, 狭窄がないか あっても $75 \%$ 末満の場合はそれぞれ $90 \%, 89 \%$ であ った.

(3) 心電図異常所見あるものの好転率は非高令者 72 \%, 高令者 48\%で, 異常のなかったものはそれぞれ 95 \%, 92\% であった.

(4) 蛋白尿あるものでは非高令者 $55 \%$, 高令者 $31 \%$ が好転し，ないものではそれぞれ 81\%，72\% が好転し た.

(5) 収縮期血圧上昇あるもの（140 $\mathrm{mmHg}$ 以上）では， 高令者の好転率が $53 \%$ であったが，非高令者のそれは $74 \%$, 上昇のないるのでは高令者 $77 \%$, 非高令者 $80 \%$ であった。

(6) 糖尿病の有無は早期予後と特に認むべき関係はな かった。

䓄問：三島博信（洞爺協会病院）脳動脈硬化度と予後 との関係に関する研究はまことに興味ある点であるが, もし椎骨動脈, 内頸動脈などの頸部動脈と脳動脈との硬 化度の相関関係について調査してあれば教えてほしい。

答 : 尾前照雄 動脈狭窄の部位については今回は考慮 していない.

\section{4. 脳卒中後遗症患者の知觉異状とその治療} 三島博信 米田達夫

(洞爺協会病院リハビリテーション・センター)

脳卒中のリハビリテーション阻害因子の 1 つとして頭 痛, 眩量, 耳鳴, 四肢シビレ感などの不定愁訴がある. その原因として脸血管の障害部位やその拡がりといった 中枢性因子ばかりでなく, 頸腕症候群, 末梢循環不全, 関節拘縮，筋痙縮などの末梢性因子も関与しているもの と考えられる.

過去 1 年間に当センターに入院した脸卒中患者 160 例 について患者の訴えを分類し，これらの愁訴と上下肢機 能, 痤性, 拘縮, 浮腫, 言語障害, 顔面神経麻瘏の有無 や程度と比較検討した。

(1)愁訴を2つに大別した. (1)頭・肩症状一頭重, 頭痛, 耳鳴, 眩暈, 難聴, 視力低下, 複視, 項部度, 肩凝り, 
一 般

(2)四肢感覚異常-知党鈍麻, 冷感, 熱感, 重圧感, 違和 感, 疼痛.

全体として (1) の訴えをするものが 66\%，(2)の訴えを するものが 58 \%あった.

(2)愁訴のあるものは, 上下肢の機能障害の軽いもの, 痤性の強いるの, 他覚的に知覚鈍麻のあるもの, 言語障 害や顔面神経麻瘏のあるもの, KWII 度以上のものに 多かった. 年令的には高令者はど多かったが 50 才以下 の比較的若いものにも少なくなかった.

(3)愁訴の 5ち頭・肩症状は, $\mathrm{KW}$ II 度以上の子の, 頸 椎骨軟骨症の変化のあるもの, 言語障害, 顔面神経麻痺 のあるものに多かった.

知覚鈍麻のあるるの, 痤性の強いもの, 浮腫のあるも のに四肢感覚異常の訴えをするるのが多かった.

(4)他覚的に知覚鈍麻のあるるのの大半に同時刺激の異 常や軀幹外側の知党鈍麻を認めた。

(5薬物療法では, 活性型 $\mathrm{B}_{12}$ はおすに四肢感覚異常に 有効だった.これに対して塩酸メクロフェノキセート， メリロートエキスは頭・肩症状ばかりでなく四肢感覚異 常にも有効だった.

\section{5. 脳卒中急性期症例の安静度に関する研 究 (第 6 報)}

一とくに患者移送扣よびリハビリテーショ ンについてー

早乙女完次 石川育成 葛 泰宏 茂木秀允 金谷春之

(岩手医大金谷外科)

脳卒中急性期患者 165 例につき, 移送前後の vital syne, 脳神経学的検査に特別な変化はみられなく, 血液 ガス分析で移送後改善を認め, 心電図は移送前後で著明 な変化はなかった.

発作から入院までの期間と症例の血清蛋白, 電解質お よび腎機能との相関を検討し, 血清総蛋白量では発作後 5〜7 日目に入院した症例で低值を示するのがかなり多 くみられ， $\mathrm{A} / \mathrm{G}$ 比も5７日目入院例で $\mathrm{A} / \mathrm{G}<1$ の例が 圧倒的多数であり, 発作 $5 \sim 7$ 日になると栄養状態の低 下, 脱水, 肝腎機能障害などが著明になることが知られ た. また残余窒素は 1 日以内に入院した例でも NPN が 高值を示し， 5〜7 日目入院例ではその傾向は著しい. PSP 15 分值では 1 日以内入院例でも25\% 以下の排泄 がほとんど全例で，7 日以後の症例でも正常排泄を示し た例は少なく卒中患者に腎機能障害例の多いことを認め,
演題

$6: 119$

更に血清電解質は各電解質とも正常值を示す例が大部分 であるが低 $\mathrm{Cl}$ 血症を示したるのが若干多くみられ，頻 回の嘔吐が影響したものと考える. 以上の成績は発作か ら入院までの期間が長びけば栄養低下, 脱水状態, 肝腎 機能障害, 電解質のアンバランス等が増悪し, さらに本 症を患家に長期間放置することなく積極的に設備の完備 した病院に入院させ適切充分な治療を加えなければなら ぬことを示している. 移送には普通乗用車を大多数例に 使用したが，2 例にヘリコプターを使用し遠距離輸送に 秀れた手段と思われた. 次に症例の早期離床, 早期社会 復帰を計るべく 1 病日より経管栄養, 体位変換, マッサ 一ジ等を行い，できるだけ早く半坐位とし，7病日には 星状神経節ブロックを施行, 14 日目ぐらいには高圧酸 素療法を併用し好結果を得ている.

然問 : 三島博信 (洞爺協会病院) 脳卒中患者の術後の 早期リハピリテーションの開始の重要性はいらまですな いが，とくに歩行開始前後の注意が重要と思われる.こ の歩行開始前後で, 再発作, 虚血発作, 高血圧脳症など の起こったような経験はないか.

問: 岩淵 勉(佼成病院内科) リハビリテーション 開始時の血圧変動の危険度をどの程度に目標を置いてい られるか.

早期の体位変換，傾斜台を利用しての立位変換をする ときの変動について.

問：田崎義昭（東邦大学阿部内科）脳卒中急性期の 移送には呼吸管理が大切で，気管切開を積極的に行った ほらがよいと思 らが，症例の何\%に気管切開を行ったか. 答 : 早乙女完次 (1)体位変換時の血圧変動は特別な基 準を持っていないが, $10 \mathrm{mmHg}$ 前後の変動で止めたい.

(2)歩行開始に際しては慎重を要するが，わたしどもで は特別な偶発症の発現は認めなかった。

(3)呼吸障害については必要を認めれば，極積的に気管 切開を行うべきであり，わたくしどもはそれだけで，意 識の回復をみた例を経験している．気管切開施行例数は 数例あるが, 正確な数は現在は覚えていない.

\section{6. 脳機能潭害に対する塭酸ビリチオキシン の臨床効果について}

竹田友彦 多襧直美 林満寿彦 松尾高明 （国立大阪南病院 内科）

井川 豊 (和歌山労災病院 中央検査科)

大阪養老院（特別養護老人ホーム）に入所中の脸循環 障害患者および老人性精神障害患者 30 例に塩酸ピリチ 
オキシン 1 日 $600 \mathrm{mg}$ を 3 力月間経口投与し, 以下にの べる結果を得た．対象となったものは，男 14 名，女 16 名, 平均年令は 78 才である.

効果判定は 1 週毎に行い, 臨床的指標としては, 頭痛, 頭重, 眩量, 嘔気, 悪心, 嘔吐, 食慾不振, 易疲労性, 注意力低下, 記銘障害, 意欲低下, 感情鈍麻, 感情失禁 等の改善を観察し，他覚的検查として，血圧，体重測定， 心電図, 脳波, 尿蛋白, 肝機能等を検討した.

著効を示したもの 5 例 $(16.7 \%)$, 有効 12 例 (40\%), 不変 10 例 $(33.3 \%)$ ，増悪 3 例 $(10 \%)$ である. 著効 例では, 食照六進, 体重増加がみられた，増悪例とは, 興奮性の現われた症例で，3例みられ，5ち1例は精神 病院へ転医させた．副作用として，搔棒感を訴えるるの 4 例あり， $5 ち 2$ 例に発疹の発生をみた．服用を一時中 止すると，4 週後には完全に消䙉し，再投与試験（1 日 /200mg）を行ったが，再投与後 $2 \sim 3$ 週後に搔棒感の 発想をみたが，発疹はみられなかった，そこで，掻痒感 を訴える患者 3 名に，ピリドキサール燐酸塩 $90 \mathrm{mg}$ の注 射を行うと，4〜 7 日間で回復した．このことよりピリ チオキシンの抗 $\mathrm{B}_{6}$ 作用もあながち否定できないと考元 られる. 他覚的検查として，ピリチオキシン投与前後に おいて, 脳波, 心電図, 肝機能等を施行したが, 血清コ レステロール值の低下の傾向がみられた以外，著明な変 化は認められなかった。

留問：長谷川和夫（慈恵医大 精神神経科） Placebo 効果をどのように考えるか。私達の老人ホームの実態調 査でも，在ホーム者は不定愁訴多く薬物投与に対する特 殊な心理状況があるのでおききする.

答：松尾高明 ピリチオキシンの効果について, placebo 使用如何との拉たづねであるが, placebo の使用は 致していない，しかし，ただいま発表しました本剤の効 果判定については，大阪養老院で本剤の投与対照となっ た老人の日常生活介助をし，本剂の投与を予知しない保 母さんによる判定で，かなりの客観性があると考えられ る.

\section{7. 老人の精神潭害に対するピリチオキシン の効果について}

\section{冨田達夫}

（新潟大 市田内科；特別養護老人ホーム松風園） 特別養護老人ホームに入居中の精神障害老人 33 例に ピリチオキシン 1 日量 $200 〜 600 \mathrm{mg}$ を使用して興味あ る知見をえたので報告する. 症例は男 14 例, 女 19 例,
6 巻 2 号 $(1969: 3)$

61 87 才, 平均 72 才. 症例は(1)老年痴呆, 脳動脈硬 化性痴呆，(2)脳卒中後遺症，パーキンソニスムス，(3)生 理的もうろくの 3 群化大別し本剂により改善された症状 をみると(1) 9 例中 6 例に自発性の増加, 行動の機敏化, 言語表現の円滑化，情動失禁の減少などを認め介護しや すくなり，(2) 9 例中 4 例は言語表現の円滑化，感情鈍麻 の回復がみられ，パーキンソニスムスの 1 例には振顫， 筋強剛, 歩行困難, 被害妄想の諸症状に改善をみず, (3) 15 例中 7 例は社交性の回復, 自発性の回復, 幻視, 不 安，失見当識の消失などが認められた.

生理的も5ろく，所謂はけを次の上5に定義した，正 常老人に比べて精神機能の低下が著しく，日常生活の適 応性は老人性精神障害に比べて充分に保たれているるの で痴呆に至らない回復可能な知能減弱またはパーンナリ ティーの変化をもつもので正常と病的との混合又は境界 状態にあるものとした. ぼけの約半数に改善をみたこと は本剂の向精神薬剤としての地位を強固なものにしたと 解釈できる.ナトリウム，ブドウ糖の脳内摄取が血液脳 関門の透過性の上昇によるものとして増加するならぼけ に見られる脳の酸素欠乏, 脳血流の減少を改善し向血流 速度を増すのであろう，本剂を用いるにあたって 1 日量 は 200 300mg で十分である. 効果がかなり早く現れ ることと副作用防止の意味から緩徐な反応を期待した方 が無難である、ばけの改善をみた場合は何等かの脳の使 用を側面から助長させる方法を講じる必要があり, 改善 後, 治療中止して悪化したものはいない。

追加：長谷川和夫（慈恵医大 精神科）前の演題の場 合と同じように，効果判定に際しての方法論において， やはり placebo 効果を考虑すべきことと思う。

䓄問：宮崎 学（大阪市立弘済院病院内科）(1)脳循環 剤を併用中のものに拈いては，ピリチオキシン投与によ って脳神経愁訴にどのような推移がみられるか。

(2)効果発現までの所要期間は如何. また無効と断定し らるまでの投与期間について。

答：冨田達夫 (1) $600 \mathrm{mg}$ では 1 力月以内は現れるの で，老人の場合，早い効果を期待するあまり，600mg を 用いることにより副作用の問題もあるので, 200 mg〜300 $\mathrm{mg}$ に止め，3 カ月をマークしている.

(2)ピリチオキシン単独使用である.

(3)春原博士始め大規模なダブルブライドシステムの研 究がなされている.この施設では今回使用しなかった。 


\section{一 般}

158. 老年者および脳卒中挠片麻瘏患者における 歩行時酸素消費量について

土肥 豊 横山 笼，打越真宏

（神奈川県老人福祉事業団七沢病院）

事故防止を目的とする歩行訓練時に拈ける負荷量の客 観的把握のための基礎資料として脳卒中後片麻疸（49〜 75 才） 30 例, ホーム収容者（65８7 才） 10 例, 健常 および軽症高血圧（41〜 74才） 36 例につき, 歩行訓練 時呼気採取，酸素消費量を測定，エネルギー代謝につき 特に歩行スピードとの関連につき検討した．健常壮年者 では歩行スピード毎分 $45 \mathrm{~m}$ 附近までエネルギー消費は 直線的増加，より高スピードでは文献上にみられる二次 関係に一致した。 したがって後者では Cal $/ \mathrm{meter} / \mathrm{kg} \times$ 毎 $\mathrm{m}$ 平均歩行時間 (秒) は一定值, 前者では Cal/meter $/ \mathrm{kg}$ それ自身または RMR/Vが一定值を示した．RMR Ｖを指標（歩行係数）として各群の差をみると老年者 は健常壮年者の上限またはやや高值, 片麻痺では異常高 值. 経過順調例では略 2 週で明らかに下降, 悪化例は上 昇を示した. 脈拍増加との関係は，心房細動例は洞調律 に比し $\mathrm{RMR} / \mathrm{V}$ の割に脈拍数の上昇が目だち, 洞調律 では薬剤の影響が $\mathrm{RMR} / \mathrm{V}$ の大きさに比し，脈の増加 の少い例も少くない。呼吸数, EKG, 血圧では一定の 関係を見出せなかった。

\section{9. 高血圧性䏚出血の外科的治療に 関する臨床神経学的研究}

一とくに血腫部位ならびに手術適応の観点よりー 金谷春之 小野寺英樹（岩手医大 金谷外科）

高血圧性脳出血の外科治療は血腫部位により死亡率が 異なる.わたくしども教室の症例では死亡率が $53.3 \%$ であるが，これを血腫部位に分けて観察すると外側型で 30.8\%, 混合型で $95.3 \%$ であり両者に著しい差がタら れる．それ故術前に血腫部位を診断し，手術適応を決定 することが重要となり，この目的のためわたしくどす教 室では術前に血腫部位を判定するために努力しているが， 神経学的所胃のみによっても比較的高率にこれを判別し らることが可能となった。すすなわち外側型では軽度意識 障害例, 瞳孔の大きさが正常な例, 対光反射陽性例扣よ び共同偏視のある例などが多くみられ，また混合型では 白血球数が 14,000 以上, 血圧が $180 \mathrm{mmHig}$ 以上, 高 度意識障害, そのうち特に 3 時間以内に高度意識障害に 俩った例, 瞳孔で左右差のある例および四肢麻痺, 痤等 のあるものなどが多くみられる。
演題

$6: 121$

これら神経学的に明らかな差があるものを R.A. Fisher の判別函数を用いて統計的に処理すると外側 型で 14. $63 \%$, 混合型で $26.47 \%$ の誤診する確率であり, 両 型の総合では誤診する確率は $25 \%$ であり，したがって 神経学的検査のみでも 75\% の血腫局在を判定しうる. 教室では,この神経学的診断法に脳血管写診断, 超音波 診断法をも併用して血腫部位診断を実施しているが，そ れによると, 手術あるいは剖検により明らかな症例の診 断成績は外側型の $80 \%$, 混合型の $70 \%$ で，かなり高率 により正確に診断しうるようになったので報告した.

質問：清水 烹 (慈恵医大 高橋内科) 血腫の局在の みが問題でなく, 血腫そのものの大きさと臨床症状の関 係はどうか.

答 : 小野寺英樹 血腫の大きさは関係する. 即ち外側 型では多くは $150 \mathrm{gr}$ 以下のものが多く, 反対に混合型は $150 \mathrm{gr}$ 以上のものが多いが，主体は血腫の大きさより血 腫局在である.

160. 老年者における脳脈管不全（第 3 報）

一その誘発時血圧と予後との関係一 高安正夫 山田良久 船坂 修

岩井信之 藤原哲司 (京大 高安内科)

[目的拈よび方法]脳卒中予知の試みの 1 つとて， 脳波を利用し自律神経遮断剂の静注と体位変換を組合わ せた脳脈管不全誘発法を考案し，実施した 77 例中 6 年 5 力月間追跡した 74 例につき予後と血圧との関係を検 討した．予後不良とはこの期間中に死亡をたは脳卒中を もったものである.

[成績括よび考按] 静注前では収縮期血圧 $\mathrm{P}_{1}$ が 140 mmHg 以下のもの 31 例中 25 例 $(81 \%)$ が予後良好, $200 \mathrm{mmHg}$ 以上の高血圧者は注涩全例不良, 拡張期血圧 $\mathrm{P}_{5}$ が $80 \mathrm{mmHg}$ 以下のもの 29 例中 23 例 $(80 \%)$ が予 後良好, $120 \mathrm{mmHg}$ 以上の 7 例中 5 例 $(71 \%)$ が不良で ある.誘発法実施中の血圧，脳波の徐波化した陽性者で はその時の血圧, 陰性者では最も下降したときの血圧で は $\mathrm{P}_{1}$ が $80 \sim 160 \mathrm{mmHg}$ では 38 例中 30 例 $(79 \%)$ で予後良好， $160 \mathrm{mmHg}$ 以上は全例不良， $\mathrm{P}_{5}$ では 50 mmHg 以下まで下降しうるものが全例良好である。次 に静注前と実施中の血圧の差では $\mathrm{P}_{1}$ が $60 \mathrm{mmHg}$ 以内 のもの 41 例中 32 例 $(78 \%)$ が予後良好, $80 \mathrm{mmHg}$ 以 上の下降です予後良好のものが 19 例中 7 例 (37\%) あ る. $\mathrm{P}_{5}$ では $10 \mathrm{mmHg}$ 以内のもの 21 例中 18 例 (86 \%)で予後良好である。この降压を静注前值比対する 
でみると $\mathrm{P}_{1} 15 \%$ 以内は 11 例中 9 例（82\%)， $\mathrm{P}_{5} 10 \%$ 以内は 19 例中 16 例 $(84 \%)$ と予後良好である. 以上 の成績より，高血圧者の予後のわるいこと．誘発により 血圧下降の小なるものは予後良好なることを知った．乙 かし，下降の大なるものでも予後良好がかなりみられる 点, 血圧以外に関係する因子があるといえる.この点は 今後検討を要するものと考える.

\section{1. クモ膜下出血の研究（続報）}

一原因, 病型, 予後と年令について一 高橋忠雄 綱島康博 江沢健一郎

清水 亨 渡辺礼次郎 高橋紹夫 平山牧彦 （慈恵医大 高橋内科）

156 例の特発性くも膜下出血自験例につき主として年 令的な面から検討を加えた. 161 例中剖検 35 例, 脳血 管写を施行せるすの 59 例であり, 脳動脈瘤を 63 例, 動静脈瘤を 13 例, 脳底部異常血管網症を 2 例に認めた. 161 例中死亡したもの 49 例で死亡率は $29 \%$. 年令分 布は 30 才から 50 才代に多く, 平均年令は 47.2 才. 女子は男子に比しやや高年令に分布する．発作に引続い て死亡したものの多くは動脈瘤例であり，40 才以上で は殆んどすべてが動脈瘤症例である.動静脈瘤は 20,30 代に集中し, 死亡せるもの 1 例である. 年令と死亡率お よび再発作との関係をみると, 初回発作死亡率は, 各年 令層で $14 \%$ 内外を示し年令別差異はない. 60 才以上で 俚第 2 回発作で半数が死亡するが， 40,50 才台では第 2 回発作での死亡率は低い。しかし発作を数回反復した 後に死亡するものが多く全経過死亡率は 40,50 代 33 $\% ， 60$ 才代 $34 \%$ と高率となる．実質障害と年例は相 関がない. 高血圧は本症の予後を決定する重要な因子で, 高血圧群では非高血圧群に比し, 再発作出現率, 死亡率 共に著しく高く, 初回発作による死亡率は非高血圧群の $16 \%$ に対し，36\%，再発作による死亡率は 33\% に対 し $51 \%$ を示し，脳実質障害を合併して死亡するすのが 増加する. 剖検および脳血管写により発見された動脈瘤 は前交通動脈扰上び中大脳動脈に位置するものが多い。 とくに後者には大型動脈瘤が多く, 脳実質に埋没する傾 向を示し，実質障害を生じやすい，加令とともに動脈瘤 経の増大と硬化所見の増強を生じ, 高血圧因子とともに 動脈瘤のより大型化への進展が推定される. 大型動脈瘤 は脳実質に埋没し，破綻時の実質障害を来たし易く、さ らに高血圧による血流ジェットの因子が，実質障害の合 併率を高めると考劣られ，これらの因子が高令者くも膜
6 巻 2 号 $(1969: 3)$

下出血の臨床上の特徴を形成するものと考える.

筷問 : 荒木五郎 (腷血管研究所 美原記念病院) 剖検 しても動脈瘤が認められない例が数例あったようですが， その剖検例の所見はどういう所見でしたか。

答 : 網島康博 剖検にて動脈瘤の認められなかったの は合計 6 例です. 5 ち 5 例は脳底部を中心に動脈精査の 機会を失したものであるが， $5 ち 4$ 例はその脳実質内出 血の様的から脳動脈動脈瘤破裂によることが推定される 症例です.脳動脈を精査して動脈瘤を発見できなかった のは 1 例である.

追加：吉田洋二（群馬大 第 2 病理）Berry aneurysm が大きくなる mechanism は, 壁の薄い部分, つまり sclerosis のないところが, 血行力学的影響によって伸展 すると考えている.

\section{2. 脳血管潭害に関する研究}

一病状安定期の再発発作一

加藤正弘 斎藤正也 長谷川恒雄

(伊豆菲山温泉病院)

相沢豊三 森 烄祐 吉田恵治

（慶大 相沢内科）

伊豆菲山温泉病院にリハビリテーションの目的で入院 した脳血管障害患者 120 名のうち入院中に明らかな脳局 所症状の増悪を示したるのは 12 例である. 入院の原因 となった大発作より再発までの期間は 1 年以内が 7 例で あり， 1 年半以上は 1 例のみである. 原疾患の病型別で は, 高血圧性脳出血 31 例中の 4 例飞, 脳硬塞 80 例中 の 7 例に, 脳塞栓, 脳動静脈奇型, 動脈瘤破裂の計 9 例 中 1 例に，それぞれ再発を認めた. 年令別では, 49 才 以下で 17 例中 4 例, 50 才代の 27 例中 3 例, 60 才代 44 例中 4 例, 70 才以上 32 例中 1 例に再発を認めた. 即ち若年群にやや高頻度である. 入院前すでに 2 回以上 の発作を起した例は，再発の頻度がやや高く，とくに原 疾患が脳血栓である群で有意に多い. 再発の神経症状は 2 例の両側麻瘦を含め, 全例に患側に認められた. かつ, 再発の神経症状はいずれも原病巣の周辺の障害に由来す るものと考えられた. 若年脳出血群では再発時の意識障 害は $20 \%$ と少なく, 全例 2 週間以内に神経症状は再発 前の状態にもどった，これに反し，老年脳血栓では， 71 \%に意識障害を認め, 5 ち 1 例死亡, 神経症状は 2 力月 以上残存する例が多い, 再発例には, 糖尿病, 高コレス テロール血症と合併するるのが多く, かつ, 安静時血圧 が収縮期 $60 \mathrm{mmHg}$ 以上または拡張期 $40 \mathrm{mmHg}$ 以上変 


\section{一 般}

動する例多い，心房細動，低血圧，腎障害は再発と関連 しない. 再発の誘因として, 脳血栓群では感染, 心理的 興奮が 70\% に認められた.

\section{3. 脳卒中における眼底出血, 乳頭浮腫 の経時的変化に対する検討}

荒木五郎 加川瑞夫 美原博

(脳血管研究所 美原記念病院)

眼底所見が新鮮脳卒中の鑑別診断括よび予後判定上, 有力な補助手段であることは既に第 9 回老年医学会総会 で発表したが, 今回は乳頭浮腫, 眼底出血の経時的変化 を中心に検討した. 対象, 過去 1 年間の入院, 往診例の らち乳頭浮腫, 眼底出血を認めた 136 例である.〔成績】 (1)乳頭浮腫は脳出血, くも膜下出血に多いが, 脳血栓で は明らかな乳頭浮腫は認められない. 眼底出血に関して は脳出血では殁どが網膜出血であり，くも膜下出血では 網膜前出血が大部分である. 脳血栓では眼底出血軽度の あのが少数例あるにすぎない. (2)発作から初診までの経 過時間で眼底变化を観察すると，1〜3 時間で軽度の乳 頭浮腫が出現している.さらに 6 12 時間では中高度 の乳頭浮腫が出現. また部分的境界不鮮明は乳頭の鼻側 次で上下にみられるものが多いが耳側のみに認められた すのはなかった. 眼底出血についてみると, 網膜出血, 網膜前出血が $3 \sim 6$ 時間で出現する. (3)眼底変化を経時 的に追及し得た網膜前出血 4 例の $5 ち$, 軽度のものは 1 力月以内に消失するが, 乳頭径大のものは約 2 力月を要 した. 乳頭浮腫では 20 日前後で更に増悪するものが 2 例みられ，吸収がややおくれる傾向があるが，一般的に は消失までに約 2 力月を要した. (4)眼底所見の左右差, 脳出血, 脳血栓では乳頭浮腫の左右差のないものと, あ るものはほほ同数であるが, くも膜下出血では左右差の ないものが多い，眼底出血においても同様のことがいえ る. (5)眼底変化の出現時期と脳卒中の予後. 48 時間以 内に観察し得た症例で部分的境界不鮮明の出現した症例 は死亡率 $10.5 \%$, 全般的境界不鮮明は $76.4 \%$, 中一高 度の乳頭浮腫は， $73.7 \%$ で極めて予後不良. 眼底出血 では死亡率, 網膜出血 $41.7 \%$, 網膜前出血 $57.1 \%$.

問：田崎義昭（東邦大学 阿部内科) (1)発作後 1 時 間にうっ血乳頭が出現したとのことであるが, 発症前, あるいは 1 時間以内に $5 っ$ 血乳頭がないことは実証され ているか.

(2軽度の5っ血乳頭の判定に問題があるが，すべて経 過をみて判定したものか.
演題

$6: 123$

答: 荒木五郎 乳頭浮腫が 1 時間後に出たといらのは, 1 時間前にはみていないので，1時間後に初診した症例 で乳頭浮腫がみられたということである. また，境界不 鮮明の推移は次第に悪化して乳頭浮腫になるものと, 軽 いものは数日にして消失するものもあるが，通常 1 2 週間で消失するものが多い。

\section{4. 脳血管写よりみた高血圧性脳出血の予後} 一とくに生命の予後と片麻㾇の予後一 加川瑞夫 荒木五郎 美原 博 (脳血管研究所美原記念病院) 富田 卓（慶大 脳神経外科）

演者独自の血管写分類によって高血圧性脳出血の予後 につき検討した。

(1)意識レベルと血管写分類：血管写正常所見を呈する もの（天幕下出血）に意識障害を呈するものが多く， II 群すなわち putaminal bleeding と群 thalamic subthalamic bleeding を比較すると, II 群では軽く, III群 に意識障害が強い,傾向にある.

(2)意識レベルと死亡について：意識レベルが drowsy から comatose になると,いずれの群に捺いても死亡率 が高くなるが，とくに I， II，IV群に著明である，III群 では軽度の意識障害でも死亡が多い。

(3)片麻瘦と血管写との関係について：II 群はIII群に比 して片麻㿁の程度は軽い傾向にあり, その改善も著しい。

(4)片麻瘦と死亡率について：I 群, II 群で片麻痺を示 すものは死亡率が著明に高い，III群，IV群では片麻㾇と の相関は認められないが，いずれも死亡率が高い。

(5)生命予後と血管写分類 : II 群では後方へ, III, IV 群 では前方へ血腫の進展を示す血管写所見を呈するものに 死亡が多い。

以上のべたように，脳血管写分類と意識レベルおよび 神経学的所見をむすびつけて, 予後を考察し, 保存的療 法の限界を求め, 手術適応の糸口とした.

\section{5. 老化脳の蛋白について（第 2 報）} 播口之朗 川瀬美枝 西村 健 市丸精一 金子仁郎 (阪大 精神神経科)

前回の報告では, 痴呆患者脳では特に白質で蛋白量の 著明な低下が認められること, アルツハイマー病脳の蛋 白了ミノ酸構成が正常者のそれと異なることを明かにし た.このことから各種痴呆患者脳では蛋白質の量的変動 
とともに質的变化が存在する可能性が示唆された．今回 は, この質的变化を acrylamide gel DISC 電気泳動法に よって検討した成績を報告する.

7.5\% acrylamide gel による DISC 電気泳動法では 正常人脳の水可溶化蛋白は, 灰白質, 白質ともにまった く同様の泳動像を示し，14 本のバンドから成る. gel の 陽極側から順にバンドを $1,2 ， 3 ， \cdots \cdots$ と仮称すると， $\mathrm{B}_{5}$ は Immunodiffusion で血清アルブミンと同じ抗原性 を示す. また $\mathrm{B}_{2}, \mathrm{~B}_{4}$ は血清, 髄液, 肝では認められず 脳組織に特異的な蛋白であることが推測される. 年令と 泳動像の関係をみると，4才以下拉よび 65 才以上では $\mathrm{B}_{4}$ の明かな減少が認められ, $\mathrm{B}_{4}$ 蛋白は脳の発育老化過 程と何らかの関係を有するものと考学られる.

アルツハイマー病, 老年痴呆では $\mathrm{B}_{2}, \mathrm{~B}_{4}$ が完全に消 失し， $\mathrm{B}_{3}$ は減少ないし消失している. 脳動脈硬化性痴 呆でも $\mathrm{B}_{2}, \mathrm{~B}_{4}$ を欠くが $\mathrm{B}_{3}$ は明瞭に認められる。痴呆 を伴な 5 Olivo-ponto-cerebellar atrophy はかなり高度 の前頭葉萎縮がみられたにもかかわらず $\mathrm{B}_{2}$ は明膫に存 在し前 3 者の萎縮とは質的に異なることが推測される.

$\mathrm{B}_{2}, \mathrm{~B}_{4}$ 蛋白の消長は脳の 発育老化や痴呆化過程と密 接な関連を有すると考えられ，それらの性状や細胞内局 在が注目される.人脳組織から抽出される水可溶性酸性 蛋白中 $\mathrm{B}_{2}$ は $5.5 \%, \mathrm{~B}_{4}$ は $5.1 \%$ を占める. $\mathrm{P}_{2}, \mathrm{~B}_{4}$ と もに核画分からは全く抽出されない。 $\mathrm{P}_{2}$ は上清, マイ クロゾーム画分, ミトコンドリア画分の順に， $\mathrm{P}_{4}$ は核 画分以外のすべての画分に均等に分布している.

$\mathrm{B}_{2} ， \mathrm{~B}_{4}$ は電気泳動や硫安分画での態度から明らかに Moor らの S-100protein とは区別される.

\section{6. 発育ならびに加令の過程における 脳脂留の变化}

山本 章 (阪大 西川内科)

成人の脳脂質の大部分はミエリンの構成脂質に由来し ている.しかしミエリンの組成が脳神経の各部分で同一 であるとい5明らかな証拠はなく，かつ白質・灰白質内 での分布括よび白質灰白質の比率も脳の各部分で異なっ ている.したがって, 発育過程の脳の変化や病理的変化 をしらべる場合，まず全脳について分析を行らのが第一 段階として重要である.

末熟児から 98 才に至る男子の全脳半側を用い, 均一 化した後, その一部をとって(1) C/M 反覆抽出, (2) Sephadex column による純化, (3DEAE-Cellulose カラム による分画，(4) 1 D〜 2 D TLC による総脂質もしくは
6 巻 2 号 $(1969: 3)$

各分画の分離，(5)各成分について，P. sphingosine, sugar. 脂酸の定量によって脂質を分析した.

脳固形分, 脂質量, およびその component の変化は, 2 才までの急速な変化と, その後の 18 才までの緩徐な 変化に大別される. 前の段階では著明な脳重量の増加を 伴なっているが, 後の段階では, 脂質の増加は含水量の 減少によって平衡されている. 加令によって脳の atrophy を来した場合には, 発育と逆行の変化を示す. 唯一 の例外は sphingomyelin で，おそらく脳血管の硬化を 反映し, 加令に伴なって持続的に増加する.

ミエリンの中にのみあるか，もしくは細胞質中よりも 多量に含有される脂質, cerebroside, sulfatide, plasmalogen PE は発育に伴って増加し，ミエリン中に比較的 少ない成分 PC. diacyl PE, PI 等は \% 組成で減少す る. 脂酸構成の変化では, 燐脂質に共通の現象は polyen の減少と, olein 酸の増加で, sphingolipids に拉いても いくつかの明瞭な法則性が認められる. 脂質組成同様, 老令の atrophy に打いて発育に逆行する変化が見られる (本研究は演者が G. Rouser の研究室に滞在中に行われ たものである).

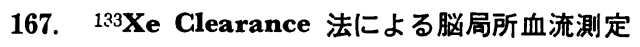 上の Geometry に関する基䃓的研究}

沢田 徹 相沢豊三 後藤文男

村松文雄 海老原進一郎 秋山 実 北村 昭 神田 直 島津邦男 江幡広太郎（慶大 相沢内科）

われわれは, 口径 $2 \mathrm{~cm}$ tapered, 同じく $2 \mathrm{~cm}$ clylindrical, 拉よび $8 \mathrm{~cm}$ cylindrical の 3 種の collimators に ついて, 寒天を充鎖したヒトの頭蓋内の ${ }^{133} \mathrm{Xe}$ の等感度 曲線を作成しこれらの collimators を用い、 ${ }^{133} \mathrm{Xe}$ clearance 法によって得た脳局所血流值の比較検討を行うと ともに, $\mathrm{N}_{2} \mathrm{O}$ 法による全脳平均血流量との比較を行い, 次のごとき結論をえた.

(1) Tapered collimator がもっとも局所性に優れてい る.

(2) Cylindrical collimator では対側半球の血流の影響 が大きい。

(3) Collimator の種類によって, 測定範囲が大きく変 り，したがって脳局所血流測定值も異った值がえられる。

(4) Collimator の種類により, fast および slow compartment $の$ weight fraction も異った值が得られる.

(5)したがって，脳局所血流を論じる場合には使用し 
一 般

た collimator についての頭蓋内での測定 geometry を 明らかにする必要がある.

(6) $\mathrm{N}_{2} \mathrm{O}$ に上る全脳平均血流量の値と, 脳局所血流 量との間には一定の相関がみられない.

問：田崎義昭（東邦大学 阿部内科） $\mathrm{N}_{2} \mathrm{~J}$ 法の測 定值と局所血流量を比較しているが, 局所血流について は左右の平均值をとって検討したか.

答: 沢田 徹 左右同時に測定し, その平均をとると いうことは行っていない。

\section{8. 超音波ドップラー法による脳循環の研究}

一総頙動脈内径の拍動性变化について一 宮崎 学 (大阪市立弘済院病院 内科)

超音波ドップラー法による脳循環測定は非観血的かつ 連続的測定という点に打いてユニークであるが，本法は 測定部位の血流速度を対象としているため, 当該血管の 内径変化の程度が問題となる.

本実験においては次の加藤の理論を応用して総頙動脈 内径の拍動性変化を検討した. $V=k^{2} r p \sqrt{s \bar{l}}$ ここに $V$ (検出音の出力電圧),$k$ (比例定数),$r$ (粒子の反射率), $P$ (超音波の音圧), $S$ (管内腔の断面積), $n$ (単位容積 中の粓子数), $l$ (管の照射域). 上式の5ち断面積 ( $S$ ) 以外の要素が一定とすると, 出力電圧 $(V)$ は $S$ の函数 となり, 本原理を応用して総預動脈内径の拍動性变化が 測定される.

今回の実験においては周波数特性が異なる 2 種類の装 置を用いた，その 1 つは血流波形を示す弁別式特性装置 であり, 他の 1 つは動脈内径変化を示す平坦特性装置で ある. 対象例は若年および壮年正常例打の打の 5 例, 高 令動脈硬化例 7 例である.

〔成績〕血流波形に関しては, 若年正常例においては 一般に連続型, 壮年正常例に打いては連続型, 中間型, 断続型の各種の波形, また高令動脈硬化例においては一 般に断続型を認めた. 一方, 内径変化に関しては, 上記 3 群の間に有意差を認めず, かつその程度は本測定法で は弁別しえぬ程度に軽度であった。

したがって理論上, 総頚動脈の血流速度は血流量のア ナログ量とみなしうると思う.

追加：田崎義昭（東邦大学 阿部内科） (100\% $\mathrm{O}_{2}$ 吸入は $\mathrm{PaCO}_{2}$ の変化を伴なうので $\mathrm{PaCC}_{2}$ 低下群では すべて CBF は減少する.

(2) $\mathrm{aCO}_{2}$ 不変群では若年者の $\mathrm{CBF}$ は低下し, 老年 郡では CBF の減少は著明でなかった.

\section{9. 脳血量について（第 2 報）}

佐藤 勤 田村 譲 岩淵貴之 高橋荘祐 高橋 暁 沓沢佾之 中村 隆 (東北大 中村内科)

脳卒中後遗症と神経疾患各々 18 例について $5 \% \mathrm{CO}_{2}$ 吸入, 過換気, $100 \% \mathrm{O}_{2}$ 吸入負荷に上る平均脳循環時 間 (MTT), , 脳血流量 (CBF), 脳血量 (CBV) 3 者の 相互変動を色素稀棌法を用いて比較検討した. 色素は一 側内顓動脈から注入し, 記録は同側内頸静脈上球で行っ た. $\mathrm{CBF}$ の変動は単一稀釈曲線に打いて負荷前後の色 素濃度面積の比較から, CBV の变動は MTT と濃度面 積の積の比から算出した.

MTT: 全例 $\mathrm{CO}_{2}$ で短縮 (-26\%), 過換気で延長 $(+38 \%)$, 一方 $\mathrm{O}_{2}$ では明らかな増減傾向を示さなかっ た $(+5 \%)$.

$\mathrm{CBF}$ : 全例 $\mathrm{CO}_{2}$ で増加 $(+42 \%)$, 過換気で減少 ($33 \%)$, 一方 $\mathrm{O}_{2}$ では約半数で減少, 残り半数で増加も しくは不変を示した $(-9 \%)$.

$\mathrm{CBV}$ : いうれの負荷に打いても約半数で増加, 残り半 数で減少傾向を示した. $\mathrm{CO}_{2}(+9 \%)$, 過換気 $(-8$ $\%), \mathrm{O}_{2}(-6 \%)$.

以上三者の相互変動を一括すると MTT と CBF には $r=0.87$ の逆相関がみられ, 両者は双曲線的関係にあっ た. $\mathrm{CBF}$ と $\mathrm{CBV}$ の变動は $r=0.71$ の正相関を示した が, $\mathrm{CBV}$ の変動は $\mathrm{CBF}$ に比し小範囲に止まり大部分 が $\pm 20 \%$ 以内であった. MTT と CBV の変動間には まったく相関を見出しえなかった.

また脳卒中後遺症と神経疾患との比較では, CBF, $\mathrm{CBV}$ とも前者は後者に比し $\mathrm{CO}_{2}$ および $\mathrm{O}_{2}$ に対する 変動率が軽度であった. MTT はいずれの負荷に対して も両者間で変動率に有意差を認めえなかった。

問：後藤文男（慶大 相沢内科） $\mathrm{O}_{2}$ 吸入によっ て CBF が増加する例は, 脳血管障害例に多かったよう

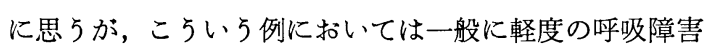
があって，動脈血の酸素飽和度が低く，したがって $\mathrm{O}_{2}$ 吸入に上り飽和度が上昇すると $\mathrm{PaCO}_{2}$ も昇すること が考えられますが, 実際に $\mathrm{PaCO}_{2}$ の変動はどうだった か.

もし $\mathrm{PaCO}_{2}$ にも血圧にも变動がなかったとすれば, $\mathrm{CBF}$ の増加機序はどういらふらに考光たらよいか.

答: 沓沢佮之 確かに $\mathrm{O}_{2}$ 吸入後 $\mathrm{CBF}$ が増加するる のがある. 原因として，これらの症例では必ずしも $\mathrm{Pa}$ 
$\mathrm{CO}_{2}$ か吸入前に比し増加していない， $\mathrm{O}_{2}$ に対する脳血 管反応性のメカニズムは血中 $\mathrm{CO}_{2}$ では説明できないよ 5に思われ，なお今後追求して行きたい。

討論：宮崎 学 (大阪市立弘済院病院 内科) $\mathrm{O}_{2}, \mathrm{CO}_{2}$, 塩パパなど投与時の脳循環変動に関しては, 局在的な脳 循環变動の他に，呼吸ないし心瀻血管系の変動に由来す る二次的な脳循環変動を考慮する必要がある.

\section{0. 老年者の脳血管反応性（第 4 報）}

阿部達夫 田崎義昭 佐野 昇 大坂 彰 上鳴権兵衛 古橋紀久 難波経彦 稲葉 允 根本 暁

成光 実 飯国紀一郎

（東邦大 阿部内科）

脳血管障害の病態の理解ならびに治療に資せんとする ために, 前報において $\mathrm{O}_{2}, \mathrm{CO}_{2}$ に対する脳血管反応性 を報告した．今回はもっとも強力な脳血管拡張剤である 塩酸パパベリン（塩パパ）を用い，脳血管反応性を検討 した. 症例は 20 才から 69 才までの 19 例で, 49 才 以下の健康者を若年群, 50 才以上の脳血管障害例を老 年群とした.

[方法] 脳血流量 (CBF) は $\mathrm{N}_{2} \mathrm{O}$ で, 血液ガス含量 は, van Slyke-Neill 法, 血液 PH, ガス分圧は Radiometer microgasanalyzer で測定した. $5 \% \mathrm{CO}_{2}$ 吸入 (3 分から 5 分), 塩パパ ( $60 \mathrm{mg}$ ) 静注時の脳血流量の変 動は, 脳 $\mathrm{O}_{2}$ 消費量を一定とみなし脳動静脈 $\mathrm{O}_{2}$ 較差 より算出した.

〔給果】 (1) $5 \% \mathrm{CO}_{2}$ 吸入で若年群の $\mathrm{CBF}$ は $51.7 \%$ 増加するのに対し老年群は $37.6 \%$ にとどまっている. 塩パパによる $\mathrm{CBF}$ の増加は若年群 $25.2 \%$, 老年群 15.8 \%でいずれの群においても $5 \% \mathrm{CO}_{2}$ による増加より 軽度であった，すなわち塩パパに上る脳血管 反応性は $\mathrm{CO}_{2}$ に対するそれとほぼ平行しており， $\triangle \mathrm{CBF} / \mathrm{PaCO}_{2}$ は若年群 4.44 , 老年群 2.48 であった. (2) $5 \% \mathrm{CO}_{2}$ 吸 入と塩パパ投与後 $\mathrm{CO}_{2}$ 吸入との $\mathrm{CBF}$ への影響を比較 した. 若年群では $\triangle \mathrm{CBF} / \triangle \mathrm{PaCO}_{2}$ は $5 \% \mathrm{CO}_{2}$ 吸入 で 4.44, 塩パパ投与後 $\mathrm{CO}_{2}$ 吸入で 4.11 と差異を示 さなかった．老年群においては $\triangle \mathrm{CBF} / \triangle \mathrm{PaCO}_{2}$ は $5 \%$ $\mathrm{CO}_{2}$ 吸入時 2. 48, 塩パパ投与後 $\mathrm{CO}_{2}$ 吸入時 3.98 で, 両群間に有意な差を認めた。

〔結語】塩酸パパベリンに対する脳血管反応性は老年 者では若年者より低下しており $\mathrm{CO}_{2}$ に対する脳血管反 応性の減少と比例する，老年群に打いては， $\mathrm{CO}_{2}$ 吸入
6 巻 2 号 $(1969: 3)$

と塩酸パパベリン投与とは相乗的に脳血流量を増加させ るが, 若年群ではかかる相乗作用は認められなかった.

問: 後藤文男 (慶大 相沢内科) $\mathrm{CO}_{2}$ とパパベリ ンを同時に用いるとそれぞれ単独で用いるよりも脳血流 増加作用が著明のようですが， $\mathrm{CO}_{2}$ の作用機序とパパ ベリンの作用機序を同じものと考兄られるか，あるいは 異なったものとお考えになるか.

答: 飯国紀一郎 $5 \% \mathrm{CC}_{2}$ と塩酸パパベリンに対す る脳血管反応性は，症例によっては差異を示すものもあ るがわれわれの例ではほぼその脳血管反応作用は平均 をとると平行しており，作用機序は同様と考㝋ておりま すが，症例を加えて検討して行きたいと思っている.

追加：後藤文男 わたくしどもは，パパベリンによっ て過呼吸の脳血管収縮作用が打ち消されることや, $\mathrm{CO}_{2}$ に対する脳血管反応性が消失したような条件下でるパパ ベリンに対する反応性は保たれていたり，その逆の場合 るあることから，両者の作用機序は異なっているものと 考えている.

答：田崎義昭：塩パパ $60 \mathrm{mg}$ を 10 分以上かけてゆっ くり静注したときには著明な頻脈，血圧上昇はなく，む しろ血圧は下降する例が多い。

頻脈, 心拍出量そのものは CBF に直接関係するもの ではなく，すべて血圧を介して脳循環に影響するものと 考光る.

\section{1. 脳循環の面よりみた老年者の}

$$
\text { 一予後と死因一 }
$$

和田行一 宮崎徳蔵 欈 紀光 山野登史 大中道 惇 花島 浩 菊地太郎 岩崎一 宮崎 正 山手昌二 木村俊三 赫 彰郎 岩根弘明 原 一男 吉村正治 新 城之介（日医大 新内科） 杉浦 昌也 飯塚 啓 飯塚循夫 （東京都盖育院附属病院）

脳循環の面から，老年者の予後と死因の関連を明かに するため, $\mathrm{N}_{2} \mathrm{O}$ 法により脳循環を測定した 134 名（合 83 , 우 51 , 平均年令 71 才) について, 12 年間にわた り追跡調査した．結果として，検査時診断と死因との関 係では脳出血 21 名中, 出血死 18 名, 硬塞死 1 名扣よ び卒中死 2 名を認めた．また，硬塞死 10 名中には出血 で死亡するるのはなく，硬塞死 6 名，循環器疾患死 2 名， その他 2 名であって生存者は 1 名あった. 脳動脈硬化症 31 名では出血・硬塞・卒中など計 12 名で, 3 名は循 


\section{一 般}

環器疾患死であった.さらに高血圧症, 循環器疾患, 呼 吸器疾患の死因についても言及した。また，死因の合計 では脳卒中群（出血 40 名・硬塞 16 名・卒中 12 名) 68 名, 循環器疾患 18 名, 呼吸器知患 8 名, 消化器疾患 3 名, その他として 18 名あるが，これは主に老衰であ り，尿毒症などもみられた．全症例 134 名の生存期間と $\mathrm{CBF}(\mathrm{m} l / 100 \mathrm{~g}$ 脳/分) は 12 年以上の生存者 19 名では CBF 53.8 で, CBF が 減少するにつれて早期に死亡し, 1 年以内の死亡 53 名で・平均 36.6 で低值を示した. とくに脳卒中群 68 名の予後と $\mathrm{CBF}$ では, 発作より 1 週以内の死亡は 16 名で, CBF は 30.7 と極めて低值を 示し, 6 力月 1 年以内のものは $40.2,1 \sim 12$ 年では 42.5 となり, CBF の減少高度のもの程予後は不良であ り, 生存期間子短かい傾向があった，以上その死因の大 部分が脳血管障害のものであることについて報告した.

問 : 山岡三郎 (警友病院) CBF を経時的に測定し, その data の悪化の度から Prognose も推定できるか.

答: 和田行一 脳循環測定検查は全症例のほとんぞが 一回検査であるが, 症例によっては同一人について 2 回 以上にわたって追求した場合もある. いずれにしても, それらからえた成績を follow up の成績, あるいは retrospective にみた成績として報告したわけである.

\section{2. 筋萎縮に関する研究}

小林 肇 西村恒夫 鶴見信男

勝沼英宇 (東医大 内科)

福沢鹿生（杉並療養所）

Aring and Cobb は筋萎縮をその原因により一次性拉 よび二次性に分類し，一次性にはさらに散発性と家族性 に発現するものとに分け, 二次性には廃用性, 外傷, 神 経炎等をあげている．老年者の筋萎縮は二次性の廃用性 の範疇に入るものと理解され，わたくしどもは老年者筋 萎縮と筋性疾患の成因を線溶系より検討したので報告し た. 対象は筋ジストロフィー症 5 例, 脊髄性進行性筋萎 縮症 2 例, パーキンソン症候群 1 例, 廃用性の5ち悪液 質 2 例, 変形性関節症 2 例, 脳軟化 3 例の計 15 例でそ の大腿筋を無菌的に採取し Astoup 法に従い, 筋エキス トラクトを作製し、フィブリン平板上に滴下しその線溶 活性值を測定した所, 廃用性筋萎縮症群では悪液質によ るものを除いていずれる線溶活性が認められず一次性筋 萎縮症群とのあいだに有意の差を認めた. すなわち老年 者の筋萎縮はその発生機序に拄いて酵素学的にも, また 免疫学的にも一次性筋萎縮と異なりむしろ老化の現象と
演題

$6: 127$

して筋の栄養障害により容積が減少する単純性筋萎縮に よることが推定される.

討論：美原 恒（神戸大 第 1 生理）大变興味深い研 究だと思う。ただ, 抽出条件として, 高張の KSCNを 用いられているようであるが，等張の中性塩溶液により 抽出されるような, アクチベーター活性の変動について も, 御研究されたらどらか.

答 : 勝沼英宇 (東医大) この問題は本年 4 月日血学会 で筋ジストロフィーと線溶系について報告したが, 今回 は老年者の筋萎縮と対比して報告させていただいた．た だいま指摘された組織片による線溶活性の検討は現在計 画しているが，今回はまだ成績が結論する迄に至らない ので省略させていただいた.

問：三島博信（洞爺協会病院）廃性萎縮例のな加に 脳軟化によるものが入っていたようにあるが，次の点を おききしたい。

(1)長期臥床者であろらか.

(2)患・健両側の対比をしているか.

(3)採取筋はどの部位からか.

たとえば，とくに筋力低下の強い部分からというこ とはしなかったのか.

問: 相沢豊三（慶大 相沢内科） Plasmin activity の六まっている脳出血例ではどうであったか.

答: 小林 肇〈美原先生へ> 筋組織自身をフィブリ ン平板上に置いての，線溶活性は，検索してありません か，今後検討してみたいと思います．筋エキストラクト 作製は 2 M. KCNS を用いた Astrup 法に従いました.

〈三島先生へ> 脳軟化症患者に扣ける筋採取部位は 患側，健側を問わず原則として肉眼的にみて，筋萎縮の 一番著明な部位とした．また症例の選択については新鮮 なものでなく，羅患後かなり長期間（数年にわたる）卧 床していた者にかぎった。

〈相沢先生へ> 廃用性筋萎縮症例については, すべ て, 長期間臥床の脳軟化症例について検討したもので, 急性の脳出血後遺症例については検索していない。

\section{3. 加令と新装置によるアキレス觡 反射について}

西亀雄二 川手亮三 和田 直 (広大 和田内科)

従来より甲状腺疾患あるいは糖尿病性神経症の一診断 法としてアキレス腱反射持続時間が測定されているが， アキレス腱反射と年令との相関性に関する検討は少ない。 
われわれは刺激時点の記録をも行いらる strain gauge 法を応用して直記式心電計を改良して臨床的に容易に描 写出来るアキレス腱反射測定装置を作製し，アキレス腱 反射持続時間と年令との相関性を検討した. 回帰方程式 および相関係数は HiPAC 103 Computer を用いて算出 した. [検査対象] 29 才以下 (162 名) · 30 49才（95 名) 50 才以上 $(122$ 名), 計 379 名の正常者. [検查 成績】 (1)反射時間 (S-A)・筋能緩の half time (D-E) は男女ともに年令とのあいだに相関を認める. (2)筋収縮 時間 (A-D) と年令との相関は男性のみに認める. (3)反 射による足底部の変位 (B-D) は男女ともに年令との相 関は認めない. (4)アキレス腱反射消失頻度は 29 才以下 $(4.9 \%) \cdot 30 \sim 49$ 才 $(7.4 \%) \cdot 50$ 才以上 $(15.2 \%)$ と 年令が進むにつれて増加. (5)同一年令群 (50 才以上) で 正常者・糖尿病 - 甲状腺機能充進症 - 甲状腺機能低下症 を比較すると, 正常群仁比し糖尿病群は反射時間・筋収 縮時間・筋弛緩の half time のいずれも延長し足底部の 変位は減少.甲状腺機能六進群は筋収縮時間・筋驰緩の half time は短縮し, 足底部の変位は増加. 甲状腺機能 低下群は筋収縮時間・筋驰緩の half time は延長し, 足 底部の变位は増加を示した。

\section{4. 筋血流代謝に関する動的研究（第 2 報）}

一脳血管障害における四肢筋血流について一 北村 昭 相沢豊三 後藤文男 海老原進一郎 奈良昌治 沢田 徹 神田 直 福内靖男 伊藤圭史 厚東篤生（慶大 相沢内科）

当教室に括いては, 先年来筋の循環怙よび代謝を研究 してきたが，その一環として，脳卒中患者の筋血流につ き検討を加兄, 脳血管障害により生じた四肢筋の機能障 害の病態生理学的解明を試みた。対象は脳卒中患者 17 名, 平均年令 56 才である. 測定法は ${ }^{133} \mathrm{Xe}$ 生食溶解液 $0.1 \mathrm{mc}$ を前腕伸筋群中に注入し，その clearance curve より筋血流を求めた.

(1)卒中患者安静時の患側筋血流は, 正常群に比して, 有意の差をもって低下しており，健側も正常群に比し， 減少傾向がみられた。

(2)手の自発的屈伸運動により, 健側, 不全麻㾇側とも に筋血流の増加を認めたが，患側に招いては増加率が小 で, 運動後の血流増加を認めなかった．

(3) passive の同様の運動では，健側，患側いずれも，筋 血流が増加したが, 両者に差はなかった. 発作後 3 力月
6 巻 2 号 $(1969: 1)$

以内， 3 力月以上の二群の間でも差は認められなかった. (4)高血圧の有無および左右別に関しては, 特に差を認 めなかった. $\mathrm{CO}_{2}$ 吸入および, 過呼吸の影響は軽微で あった.

(5)麻瘦の程度による血流の差は明らかにし得なかった。 以上脳卒中患者に扣いては, 循環障害が脳のみにとど まらず，四肢筋においてる認められることを明らかにし た.これら循環障害の要因が脳卒中発作という stress そ のものにあるのか, 発作以前にすでに，これ等の病変が 存在したのか等につき, 今後さらに症例を増やして, 発 作後の経過観察等, 各種負荷実験により, 解明したい.

答: 北村 昭 浮腫の有無による筋血流の差異につい ては今回は検討を加えていないが，今後例数がふえれば， 知覚障害の有無, 自律神経障害の有無, 筋萎縮の程度, 筋 tonus, 強直の有無等についても検索を行いたい。

\section{5. 脳血管稘害と血清尿酸}

原田歳久 土屋博文 道川建一 村上恵一 大川日出夫 野口八郎

（永寿総合病院 内科）

降圧剤で高尿酸血症を来すものがあり, 高血圧治療時 の尿酸の態度は注目をひいているが, 脳血管傷害群の血 清尿酸の態度を観察した.

対象は昭和 41 年 4 月より 43 年 5 月の期間に当院内 科に入院し，血清尿酸を測定し得た 89 例で，内訳は脳 出血 17 (全例男), 脳血栓男 44 , 女 23 , 脳塞栓男 2 , 女 3 である. 年令は 89 例中 83 例が 50 才以上. 測定 は大部分の例で入院当日または翌日行った.

血清尿酸值は, 脳出血男 $6.9 \pm 2.9 \mathrm{ng} / d l$, 脳血栓男 6.9

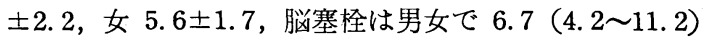
で, 健康例に比して有意の増加は認めがたいが, 高い值 を示す傾向にあり，これを分布の％でみると，尿酸値 $8 \mathrm{mg} / \mathrm{dl}$ 以上のものは, 健康 $3 \%$, 高血圧や糖尿病 $7 \%$ に比して脳血管傷害群は 20 36\% の間で, 健康群の 10 数倍の多きを示し, 過半数が $6 \mathrm{mg} / \mathrm{dl}$ 以上であった.

生存例, 死亡例で尿酸值に差はみられないし, 年令, 最高圧血, 蛋白尿の有無で, 脳血管傷害群の血清尿酸値 をみたが，一定の傾向はみられなかった。

男女の例数が比較的そろっている脳血栓を例にとって， その発病前からもっていた基礎疾患（高血圧, 糖尿病, その他の疾患, 既往症のないもの）と尿酸の関係は, 一 定の傾向がみられなかった．発病から尿酸測定までの期 間を 2 日を境に比較したが，平均值からは 2 日以内のも 


\section{一 般}

のがやや高い值を示したが, 有意とはいい難い, 発病時を 基点として，その前と後の三ッの病期で尿酸值を比較し たが，その推移は種々で一定の傾向ははみられなかった。

相問 関係は.

答：原田歳久 脂質代謝との関係は, 目下検討中.た だ，尿酸とコレステロール值とは特有の関係はみあたら ない。

問 : 山口明志（昭和大 成人病科）尿酸の推移につ いて, 発病前, 後の薬物の影響等について検討されてい るか.

答：原田歳久 発病前, 未治療のもの, あるい怡療 中断していて発病したものが多く, 入院時の測定につい ては，薬剤の影響は考慮しなくてすんだ.

\section{6. 脳卒中後䝵症患者の尿路障害について}

三島 博信

（洞爺協会病院リハビリテーション・センター）

垂水 泰

（伊達日赤病院 泌尿器科）

脳卒中のリハビリテーションでも排尿障害や尿路疾患

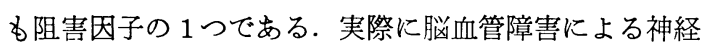
因性の排尿障害も決して少なくないといわれている。し かしながら脳卒中患者には高令者が多いために痴呆化に よる中枢機能の低下や器質的な尿路通過障害によるもの も十分に考虑しなければならない。

当センターに入院した脳卒中患者 119 例について尿回 数, 尿所見を調べ，異常のあったものに残尿測定，尿道 撮影, 膀肶鏡検査, 膀羘内圧測定を行った. 対照群とし て 51 才以上の一般入院患者 100 名を打いた.

症例は男性 85 名, 女性 34 名, 平均年令 57.5 才, 発病よりの経過期 2 年 5 力月である.このうち神経因性 膀胱之診断されたものは 49 例， $42 \%$ であった. 残尿感 や排尿障害などの愁訴のあるものが全体の $20 \%$, 神経因 性膀胱のあるものの $35 \%$ にあった．頻尿〜失禁のある るのはほほ全体の $70 \%$ ，尿所見に異常のあるものは 50 \%であった. 合併症は前立腺肥大 18 , 膀胱結石 1 , 糖 尿病 5 であった，身体機能との対比では機能のわるいる のに多かったが，とくに下肢の歩行能力のわるいものに 神経因性膀胱のあるものが多かった。またこれらでは顔 面神経麻瘦, 言語障害 (構音障害) のあるものが多かっ た. 膀脱鏡検查では 50\% に充血, 䕀室, 滤泡, 肉腫形 成などの変化があった．また青試験では $21 \%$ に排出遷
演題

$6: 129$

延を認めた. PSP では 50\%のものに腎機能の低下があ った.

膀胱内圧の測定では大半に残尿があり, 過半のものに 膀胱容量が小さくなっていた.

以上脳卒中後遺症患者にみられた尿路障害, とくに神 経因性膀胱について報告した。

問： 後藤文男 (慶大 相沢内科) (1) forced grasping その他, 前頭葉症状の有無との関係は如何だったで あろらか.

(2)病巣の部位との関係を調べておられたら教えてほし い.

答: 三島博信 (1)前頭葉症状のあるもののほうがない もののほうよりも多かったと思う.

(2)剖検をしていないので, くわしいことはわからない が, 構音障害のあるものに多かったこと, 下肢の歩行能 力とに強い相関関係があったことは脳の出現頻度に障害 部位を推定させるのではないかと思う。すなわち, 定型 的, 内包後脚後 $1 / 3$ 部の障害例にも神経因性膀胱のある ものがあると考えている.

問：田崎義昭（東邦大 阿部内科）脳卒中後の尿失 禁には Demenz が関連するものが多いが, 尿失禁と知能 との関係はどらか.

答: 三島博信 確かに痴呆化のあるものに多いが，ま ったく正常な知能のものにも神経因性膀脂があり, 失禁 の状態にあるものも数例ある.

追加：相沢豊三（慶大 相沢内科）尿路障害は人手を 要する一番困っだ状態で, 病態をよくきわめて, 処置管 理の工夫に今後のご労力をつづけていかれたい.

\section{7. 脳卒中患者の治療効果判定に関する 試み（第 2 報）}

一言語表音読速度の加令変化について一 奈良昌治 相沢豊三 後藤文男

村松文雄 秋山 実 福内靖男 島津邦男 伊藤圭史 厚東篤生 江幡広太郎

（慶大 相沢内科）

脳卒中拈よび各種神経疾患における言語障害の程度を 定量的に表現する目的で製作した慶大式言語表を, 健康 者 485 例, 脳血管障害その他の疾患例 145 例, 計 633 例に用いて, 言語能力と, 年令, 性, 職業, 学歷, 練習 効果, 眼底血管変化, 脳波, 脳循環諸量などとの関係に つき基璴的な検討を加えた，健康者においては，学童期 より青年期にかけ，言語表音読能力は急速に上昇し， 17 
才から 19 才に頂点に達するが，21〜2 才から, 早くも 加令に上る減衰傾向が出現し，その後はほほ直線的に低 下の一途をたどる. 同年代においては, 性, 出身地と音 読数は関係なく，学歴の高さとは有意の相関を認める. 練習効果は健康者では全例に認め, 増加率平均は $12 \%$ であったが, 脳卒中群では練習効果はまちまちで, 増加 率は 6.6\% に止まった. 眼底血管変化との関係は, 無変 化群の平均が $356.7 \pm 77.7$ 語に対し, 動脈硬化性变化 Scheie I 度より II 度の 有変化率の平均が $318.7 \pm 75.6$ 語と有意の低下を認めた，安静閉眼時脳波で，後頭部の 基本波に出現した最少の周波数が 7 cycle のものが平均 253. $8 \pm 49.7,8$ cycle 群 $342.1 \pm 57.8,9$ cycle 群 347.9 \pm 77.1 と, 7 cycle 波の出現したものに有意の低下を認 めた．前頭部に打ける速波の混入率との相関は認めなか った. 脳血流量, 脳血管抵抗, 脳酸素消費量とは全く相 関を認めなかった．以上，言語表の音読能力を規定する 最大の因子は年令であり，また，学歴，あるいは Intelligence 子関係する. さらに眼底血管硬化度, 脳波の基本 波周波数とも相関を認めた．終りに，各疾患における言 語表音読数の比較，および言語表を用いて経過を観察し た 3 例の症例を示した。

問：金子仁郎（阪大 精神神経科）音読速度と脸波 との関連性のうち，側頭部の脳波の異常性との関連性い かん.

答：奈良昌治 わたくしどもの脳波検査では，健康人 の身体検查の多数例を使用している為, 脳波のリードの 数が限られていたため, 側頭部脳波は撮影出来ませんで した. 今後, 検討を加えていくつもりである.

\section{8. 脳卒中の研究（第 49 報）}

一脳血栓による失語症の日米の比較一 永江和久 勝木司馬之助 岡山昌弘 吉沢僖教 後藤幾生 三好 甫 (九大 勝木内科)

H. M. Schuell (Aphasia Section, Neurology Service, Veterans Administration Hospital, Minnesota, U.S. A.)

1961 年 12 月よりミネンタ大学との脳卒中の共同研究 の一環として脳血栓において失認症の病型, 重症度, 経 過なぞについて比較検討を行なった.

[対象]脳血栓発病後 3 力月以内に失語症検査がなさ れた 267 例（九大, 平均年令 59.1 才，ミネンタ 146 , 66.7 才)である.
6 巻 2 号 (1969:3)

失語症検査，九大では失語症鑑別診断法およびその簡 易法のわれわれによる日本語訳を，ミネンタ例では失語 症鑑別診断法を用いた.

〔成績】 I 失語症分類：1群 Simple Aphasia; 九大 4 例 $(13 \%)$, ミネンタ $3(5), 4$ 群 Aphasia with scattered disturbances; 九大 3 (9), ミネンタ 31 (53), 5 群 Severe aphasia; 九大 6 (19), ミネンタ 10 (17), 7 群 Mild aphasia with persisting dysarthria; 九大 9 (28), ミネソタ 1 (2), II 重症度: 軽症; 九大 15 (47), ミネ ソタ 7 (12), 中等症; 九大 3 (9), ミネンタ 31 (53), 重症; 九大 9 (27), ミネンタ 12 (21), III 1 年後の状 態: 改善; 九大 16 (64), ミネソタ 13 (32), 不変; 九 大 5 (20), ミネソタ 6 (15), 覀化; 九大 1 (4), ミネ ソタ 6 (15), IV 非失語例 : 正常; 九大 81 (91), ミ卒 ソタ 20 (22), 構音障害; 九大 5 (6), ミネンタ 6(7), 視覚認知障害; 九大 1 (1), ミネンタ 11 (13), 視空間 障害; 九大 0 , ミネンタ 12 (14), 構音障害十精神症状 (痴呆など); 九大 1 (1), ミネンタ 14 (16).

以上, 九大例はミネソタ例より 1 群 7 群の失語症が多 く, 失語症の重症度も軽いものが多かった. 1 年後の回 復がよかったものが多く，また非失語症例については失 行失認症状および痴呆などの症状を呈した例は少なかっ た。これらは両者失語症の本質的な差異を反映している とはなしがたいが，われわれの例は脳の器質的障害の程 度が軽く，障害部位が相違していたであろうことによる と考えられる。

留問：三島博信（洞爺協会病院)CVAの患者に cedem の出現するものが可成りあると思う。このようなるのと, oedem のないものとの間に匹肢血流量の差はなかったか.

犋問：三島博信（洞爺協会病院）(1失語症の第 1 群に も重症例と軽症例とがあるが，演者の経験にはどうか.

(2)失語症と構音障害のあるものはどのぐらいあったか.

(3)平均治療期間はどのくらいか.

答 : 永江和久 (1)本報告は自然経過をみたもののみを のべ訓練例は含まれていない.

(2)第 1 群について，わたくしどもが取扱ったものにつ いては軽症で予後が良好であったものばかりでしたが， 第 6 群 partial auditory imperception がその回復過程 で第 1 群類似の症状を呈することはあると思います．そ のよ5なものを第 1 群に含めますと, 第 1 群がさらに 2 つの subtype に分けられると思います.

(3)第 4 群についてはわたくしどもの場合脳血栓より脳 出血例に多くみられた。 


\section{一 般}

(4)失語症に構音障害が加わった第 7 群の頻度は私共で は脳血栓による失語症 32 例中 9 例 (28\%) である. 必 ずしも頻度が低いとは考觉られない。

\section{精 神}

\section{9. 家庭老人の社会精神医学的研究一}

一痴呆患者を中心として一

市丸精一 井上 修 福井昭平 井上文男

小车田清博 金子仁郎（阪大 精神神経科）

昨年までの調査の結果, 痴呆性疾患と関連の深い因子 として, 年令, 学歴, 社会的条件 (社会参加の状態, 職 業の有無, 職歴, 余呢利用の状況など) 精神的条件（役 割意識, 淋しさ, 孤立感など), 身体的条件（視力, 聴 力, 言語障害など)，があげられた，しかしながら，痴 呆のある者とない者との, これらの生活構造上の相違点 が，ただちに痴呆性疾患の発症に動的に関与するとは結 論しえない，この点を明らかにするため, 痴呆のない者 が，いかなる身心の条件のもとに痴呆に移行するか，ま た痴呆患者がどのような推移を示すかについて追跡調查 を開始した。

昨年調査時，痴呆なしと判定された者 213 名につき調 查した結果では，軽度痴呆に移行せるもの 52 名，中等 度以上の痴呆に移行せるもの 3 名を見出した．死亡，不 在, 調査拒否等で調査し得なかったものは 35 名である。 昨年調査時, 痴呆なしと判定された群と痴朵ありと判 定された群について，過去 1 年間の死亡率を比較したと ころ, 痴呆のない群では死亡率 $3 \%$, 痴呆群では死亡率 35\%で，両群間に明らかな差がみられた。

昨年度調査時に，身心の条件のよかった群と，わるか った群について，1年後の痴呆の発症率を各因子ごとに 比較したが，両群間に有意の差はみられなかった。

昨年度調査時に，身心の条件のよかった者の中，本年 度調査時までに, これら条件に変化のなかった群と, 条 件の悪化した群とにつき, 痴呆の発症率を比較したが, 両群間に有意の差を見出しえなかった。

昨年までの横断的調査で，痴呆の有無に関連深いとさ れた因子について，1年後に維断的に調査した結果では， これらの因子が，痴朵の発症に関与するや否やの結論は えられなかった．これは調查期間が短いために有意の結 果がえられなかったのか，劣るいはこれらの因子は痴呆 の発症には無関係であるのか. 今後の追跡調査により検 討したい。
180. 入院老年期精神疾患の社会精神医学 的研究（第 1 報）

池田 輝彦

（京府医大 精神神経科; 十全会京都双岡病院）

児島幸照 福島䫓三(京府医大 精神神経科)

$$
\begin{aligned}
& \text { 東 昂（十全会京都双岡病院） } \\
& \text { 飯塚礼二（京府医大 精神神経科） }
\end{aligned}
$$

従来わが国では，老年期精神障害者の入院率が低いと されて扣り，しかも入院患者には社会的家族的背景が潜 在していることが多いとされている. 十全会京都双岡病 院に入院中の 60 才以上の患者を対象に, そのうちある 程度の成績がえられた 100 名につき発表する.

方法は 8 頁にわたる調査用紙を作製，入院時家族およ び患者より聴取, その後家族面接, 家庭訪問等をなし, また一方, 精神症状, 身体症状, 各種検査所見より診断 を分類し, 各人の入院理由より, A 群 : 純粋にその精神 症状によって, 入院を必要とするに至ったもの, B 群 : 社会的・家族的要因が中心となっているもの，C群：病 状と社会的・家族的要因の両者を兼ねそなえるもの，の 3 群に分類し, 年令, 性別, 家族の構成, 家族の状況, 経済状態, 入院経路, 職業, 学歴, 宗教などの因子との 相関を検討した.

その結果, 精神身体症状によるほか, なんらかの社会 的・家族的要因の加わっているものが全体の $26 \%$, む しろ社会的・家族的要因が中心となっているものが 24 \%存在した.

老年入院精神疾患患者においては, 本来の精神症状の 程度を問わず, 年令, 性別, 保護者, とくに配偶者, 子 供の有無, 家族とくに子供の示吉心的態度や考え方, 本 人および家族の経済状態, 職業や生活能力, 学歴や本人 の生活態度や性格等が入院理由に大いに関与しているこ とが明らかとなった. わたくしどもはさらにこれら社会 的, 家族的要因が患者の入院といら事実に伴なって, 時 間的にどのように推移していくかを次の問題として検討 をすすめている.

\section{皮房・毛 繁}

181. 老年者の皮后機能に関する研究（第 3 報）

真田 勲 村上元孝 関本 博 安田義顕（金沢大 村上内科）

われわれは皮膚の老化防止を目的として老年者の皮膚 機能について検討を加えてきたが，今回は皮膚の老年性 変化と単位時間での皮虐の水分放出量との関係について 